Article

\title{
Novel Insights on the Toxicity of Phycotoxins on the Gut through the Targeting of Enteric Glial Cells
}

\author{
Océane Reale *, Antoine Huguet and Valérie Fessard * \\ ANSES, Fougères Laboratory, Toxicology of Contaminants Unit, French Agency for Food, \\ Environmental and Occupational Health \& Safety, 35302 Fougères, France \\ * Correspondence: oceane.reale@anses.fr (O.R.); valerie.fessard@anses.fr (V.F.); Tel.: +33-0230438011 (O.R.)
}

Received: 21 June 2019; Accepted: 19 July 2019; Published: 23 July 2019

\begin{abstract}
In vitro and in vivo studies have shown that phycotoxins can impact intestinal epithelial cells and can cross the intestinal barrier to some extent. Therefore, phycotoxins can reach cells underlying the epithelium, such as enteric glial cells (EGCs), which are involved in gut homeostasis, motility, and barrier integrity. This study compared the toxicological effects of pectenotoxin-2 (PTX2), yessotoxin (YTX), okadaic acid (OA), azaspiracid-1 (AZA1), 13-desmethyl-spirolide C (SPX), and palytoxin (PITX) on the rat EGC cell line CRL2690. Cell viability, morphology, oxidative stress, inflammation, cell cycle, and specific glial markers were evaluated using RT-qPCR and high content analysis (HCA) approaches. PTX2, YTX, OA, AZA1, and PITX induced neurite alterations, oxidative stress, cell cycle disturbance, and increase of specific EGC markers. An inflammatory response for YTX, OA, and AZA1 was suggested by the nuclear translocation of NF-kB. Caspase-3-dependent apoptosis and induction of DNA double strand breaks $(\gamma \mathrm{H} 2 \mathrm{AX})$ were also observed with PTX2, YTX, OA, and AZA1. These findings suggest that PTX2, YTX, OA, AZA1, and PITX may affect intestinal barrier integrity through alterations of the human enteric glial system. Our results provide novel insight into the toxicological effects of phycotoxins on the gut.
\end{abstract}

Keywords: enteric glial cells; phycotoxins; toxicity; high content analysis

\section{Introduction}

Phycotoxins, mainly produced by dinoflagellates, can accumulate in filter-feeding bivalves and provoke human intoxications with clinical symptoms ranging from intestinal to neurological effects [1]. On the basis of their physico-chemical properties and their biological effects, phycotoxins are classified into different groups. Despite the fact that no human fatalities have been reported with lipophilic toxins, the recurrent presence of both regulated and non-regulated lipophilic phycotoxins (including emerging analogs) in shellfish remains a global concern for human health [2]. Among these phycotoxins, pectenotoxin-2 (PTX2) and yessotoxin (YTX) have never been proven to be involved in human intoxications, although toxic effects have been documented in rodents after oral exposure [3,4]. Okadaic acid (OA) is known to induce nausea, diarrhea, vomiting, and abdominal pain in humans [5]. Azaspiracid-1 (AZA1) provokes similar symptoms with nausea, vomiting, diarrhea, and stomach cramps [6]. No human intoxication has been described so far from the cyclic imine 13-desmethyl spirolide C (SPX) [1], although significant concentrations are regularly detected in shellfish [7]. Recently, analogs of palytoxin (PITX), an amphiphilic phycotoxin, have been detected in marine organisms of the Mediterranean Sea [8] without any report of human intoxication through seafood consumption in this area. However, PITX has been involved in human intoxications in tropical and sub-tropical areas inducing both neurological and gastro-intestinal symptoms with sometimes human fatalities due to myocardial injury [8]. All these toxins have been shown to act through rather distinct targets. PTX2 inhibits actin polymerization $[9,10] ; \mathrm{OA}$ is a potent serine/threonine protein-phosphatase inhibitor, 
which therefore may affect numerous cellular processes [11,12]; SPX is known as an antagonist of muscarinic acetylcholine receptors [13]; and PITX is a potent inhibitor of the $\mathrm{Na}^{+} / \mathrm{K}^{+}$ATPase [14-16]. On the contrary, the targets for YTX and AZA-1 have not been clearly elucidated [17].

Since ingestion represents the main route of human exposure to phycotoxins, the intestine, one of the first organs in contact with food contaminants, can be greatly affected, as underlined by the gastro-intestinal symptoms observed in humans. Oral exposure of rodents has been associated with intestinal damage such as intestinal microvilli disorder [18], dilatation of the small intestine [19], and cell detachment with the separation of the lamina propria from the epithelium [20]. Moreover, in vitro studies have demonstrated the toxicity of lipophilic phycotoxins on human intestinal epithelial cells (IECs) [21-23].

The intestinal epithelial barrier (IEB) is a highly dynamic and specialized system composed of several cell types such as enterocytes, goblet cells, endocrine cells, and $\mathrm{M}$ cells. Recent scientific advances have pointed out that other cells, present in the mucosa, can interact with IECs. Among these cells, enteric glial cells (EGCs), belonging to the enteric nervous system, are found from the ileum to the colon [24]. Due to their close proximity [25,26], physiological crosstalk between EGCs and IECs has been shown to be important for the regulation of homeostasis, gut functions, and intestinal barrier permeability [27]. In vivo rodent models with EGC deletion showed a clear disruption of the IEB [28] with intestinal inflammation [29], persistent diarrhea [30], and loss of barrier integrity [31,32]. EGCs control IEC functions [33] through the release of mediators such as glial cell-derived neurotrophic factor (GDNF), brain cell-derived neurotrophic factor (BDNF), S-nitrosoglutathione (GSNO), and 15dPJGP prostaglandin derivate [34,35].

The ability of some phycotoxins to cross the IEB and/or alter its integrity $[23,36,37]$ suggests that cells beneath the epithelium, including EGCs, could be exposed to these toxins. Data in the literature demonstrated that an AZA1 oral treatment of mice induced a peristalsis arrest [19], suggesting alteration of the enteric nervous system. In vitro, the permeability of an IEC monolayer was affected by $\mathrm{OA}$ through the secretion of neuropeptide $\mathrm{Y}$ by neuroblastoma cells [38]. However, to date no study has investigated if phycotoxins can directly impact the enteric nervous system, and particularly EGCs.

In this context, we aimed to evaluate and compare the cellular responses of six phycotoxins (PTX2, YTX, OA, AZA1, SPX, and PITX) on the rat EGC cell line CRL2690. Neunlist et al. have shown that there are no interspecies differences between rat and human EGCs and that similar interactions with human IECs were observed [26]. Moreover, it has been underlined that the EGC2690 cell line is close to primary rat glial cells regarding glial key markers [39]. We therefore investigated cell viability, morphological cell changes, oxidative stress, inflammation, cell cycle, and specific glial markers including glial fibrillary acidic protein (GFAP), calcium-binding protein (S100 $\beta$ ), and nitric oxide synthase (iNOS) using RT-qPCR and high content analysis (HCA) approaches.

\section{Results}

\subsection{Cytotoxic and Morphological Effects of Phycotoxins}

After a $24 \mathrm{~h}$ treatment of EGCs, a dose response curve was obtained with four toxins (Figure 1), and $\mathrm{IC}_{50}$ were determined as follow: $\mathrm{YTX}=14.5 \pm 11.1 \mathrm{nM}, \mathrm{OA}=75.9 \pm 9.2 \mathrm{nM}, \mathrm{AZA} 1=7.0 \pm 7.5 \mathrm{nM}$, and PITX $=0.4 \pm 0.1 \mathrm{nM}$. No significant cytotoxicity was observed following treatment with PTX2 and SPX up to $64 \mathrm{nM}$ and $127 \mathrm{nM}$, respectively. 

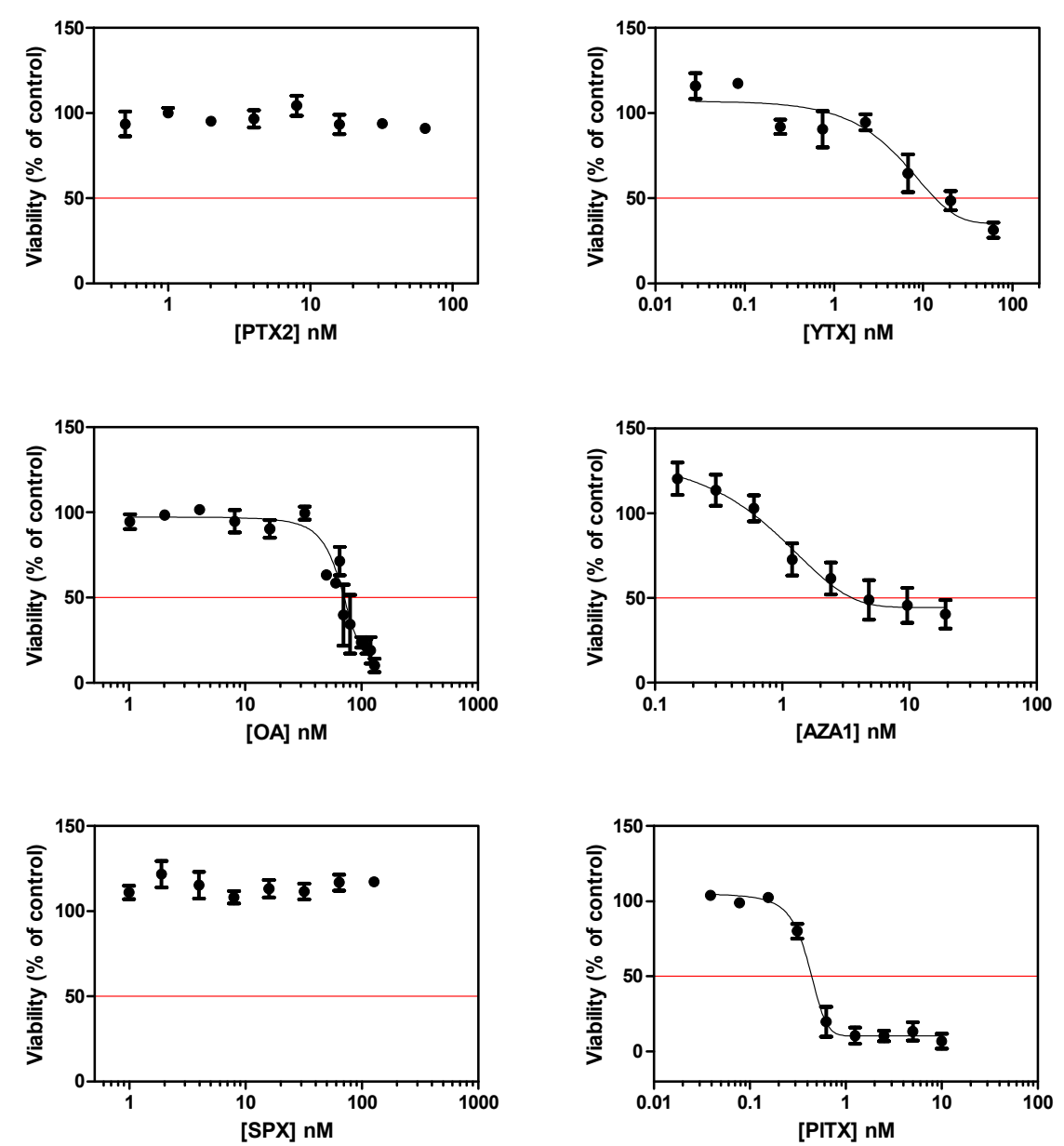

Figure 1. Cytotoxicity on enteric glial cells (EGCs) after a $24 \mathrm{~h}$ treatment with pectenotoxin-2(PTX2), yessotoxin (YTX), okadaic acid (OA), azaspiracid-1 (AZA1), 13-desmethyl spirolide C (SPX), and palytoxin (PITX). Cytotoxicity was measured by the neutral red uptake assay (NRU). Values are presented as mean \pm SEM and expressed as percentages relative to the vehicle control medium. Three independent experiments were performed.

Morphological modifications were also observed (Figure 2). The EGCs from the vehicle control exhibited neurite branching characterized by a broad network. Different morphological modifications were induced depending on the toxin. Although no effect was detected with the neutral red uptake (NRU) assay, PTX2 induced neurite atrophy from $16 \mathrm{nM}$ and was the only toxin where rapid effects on morphological modifications were observed (at $3 \mathrm{~h}$; data not shown). From $10 \mathrm{nM}$ YTX exposure, neurite alterations were observed, with cells presenting few neurites at the highest concentration. From $32.5 \mathrm{nM}, \mathrm{OA}$ induced a concentration-dependent cell elongation as well as cell rounding. Neurite atrophy and cell shrinkage were observed with $2.4 \mathrm{nM}$ AZA1 and above. No morphological effects were noticed with SPX treatment up to $127 \mathrm{nM}$. Above $0.3 \mathrm{nM}$ PITX exposure, cells depicted an irregular shape combined with a blebbing of the body cell and a loss of neurites. 

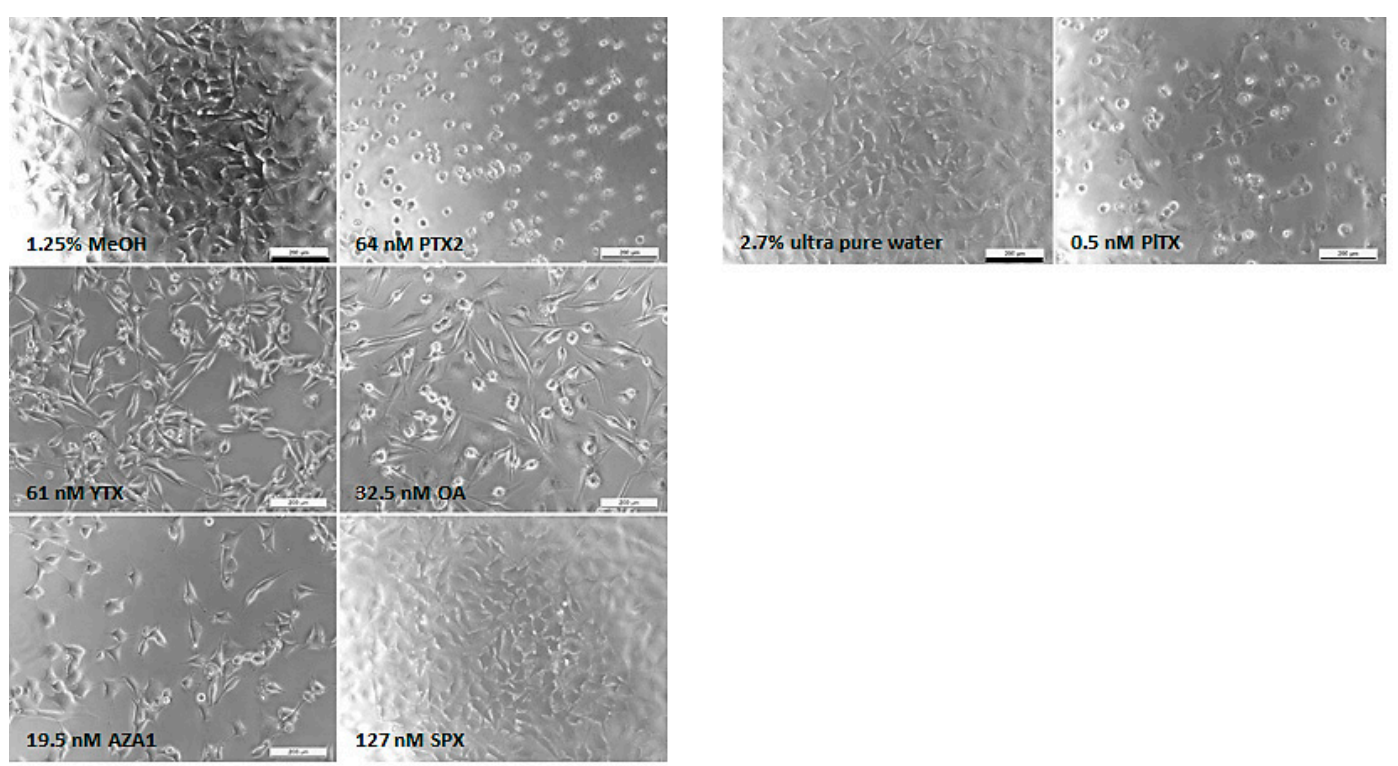

Figure 2. Morphological modifications of EGCs after $24 \mathrm{~h}$ exposure to PTX2, YTX, OA, AZA1, SPX, and PITX. Evaluation of cell morphology was carried out by phase contrast microscopy. Each image is representative of three independent experiments. Vehicle controls: $1.25 \% \mathrm{MeOH}$ and $2.7 \%$ ultra-pure water (for PITX only). Scale bar $=200 \mu \mathrm{m}$.

\subsection{Intermediate Filament GFAP and Cell Body Area}

After $24 \mathrm{~h}$ of treatment, a significant modification of GFAP levels was observed with all the toxins except SPX. A concentration dependent increase in GFAP was induced by PTX2, YTX, and AZA1 reaching 2.3-fold, 1.7-fold, and 1.8-fold, respectively, at the highest concentration (Figure 3). OA induced a significant increase in GFAP levels (1.6-fold) but only at the highest concentration. PITX induced a decrease of GFAP levels $(-38 \%)$ at the highest concentration $(0.5 \mathrm{nM})$. PTX2 (from $4 \mathrm{nM}$ ) provoked cell shrinkage and then significantly reduced cell body area of EGCs up to $-40 \%$ at $64 \mathrm{nM}$. YTX exposure showed a slight but non-significant reduction of the cell body area $(-12 \%$ at $61 \mathrm{nM})$. OA did not induce any modification of the cell body area. AZA1 also induced a decrease of the cell body area from $2.4 \mathrm{nM}$, reaching $-22 \%$ at $19.3 \mathrm{nM}$. On the contrary, PITX induced a $+38 \%$ increase of the cell body area at $0.5 \mathrm{nM}$ that is in accordance with the depicted blebbing of the cell body. No alteration of GFAP amounts and cell body area were observed with SPX treatment. 

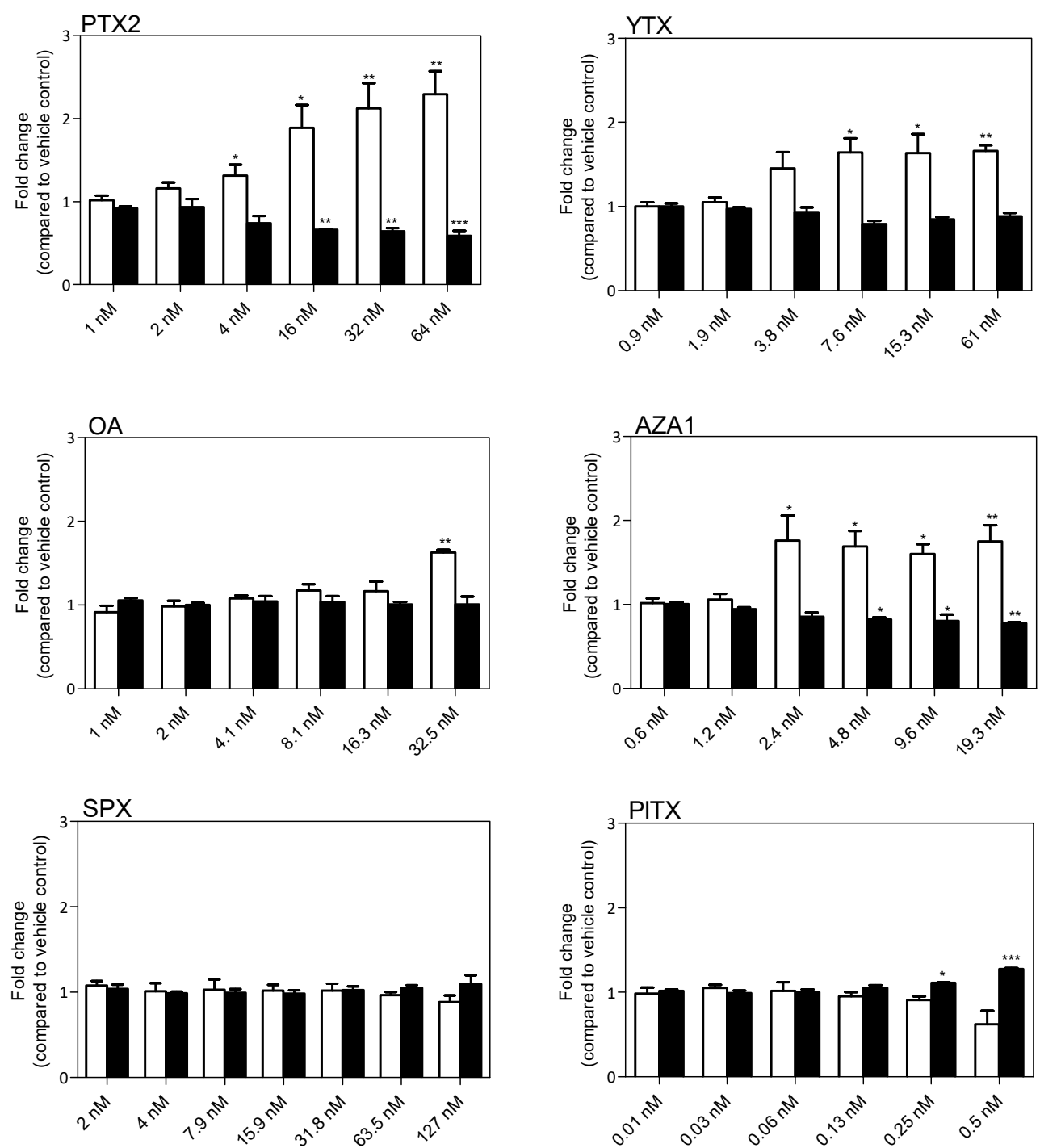

Figure 3. Glial fibrillary acidic protein (GFAP) levels and cell body area in EGCs after $24 \mathrm{~h}$ exposure to PTX2, YTX, OA, AZA1, SPX, and PITX. GFAP levels (white) and cell body area (black) were carried out by Hight Content Analysis (HCA). Values are presented as mean \pm SEM and expressed as fold change compared to the vehicle control set to 1 . Three independent experiments were performed. ${ }^{*}, * *$ : values significantly different from the vehicle control (respectively $P<0.05$ and $P<0.01$ ).

\subsection{Cell Cycle Analysis}

The cell cycle of EGCs was modified following $24 \mathrm{~h}$ treatment with 5 out of the 6 toxins (Figure 4). However, with the exception of PTX2, the modifications were not statistically significant. Following treatment with PTX2, YTX, OA, and AZA1, the subG1 phase was 2.2- to 7.2-fold higher than the control depending on the toxin. PTX2 increased the proportion of both G2/M and polyploid cells concomitantly with a decrease in G0/G1 cells. At the highest concentration of YTX, a slight reduction in the number of G2/M cells and an increase of the number of cells in $S$ and G0/G1 phases were observed. AZA1 exposure induced a reduction in the percentage of cells in S and G2/M phases. PITX and SPX did not induce any significant modification of the cell cycle progression, except a slight decrease of cells in S phase for SPX at the highest dose. 

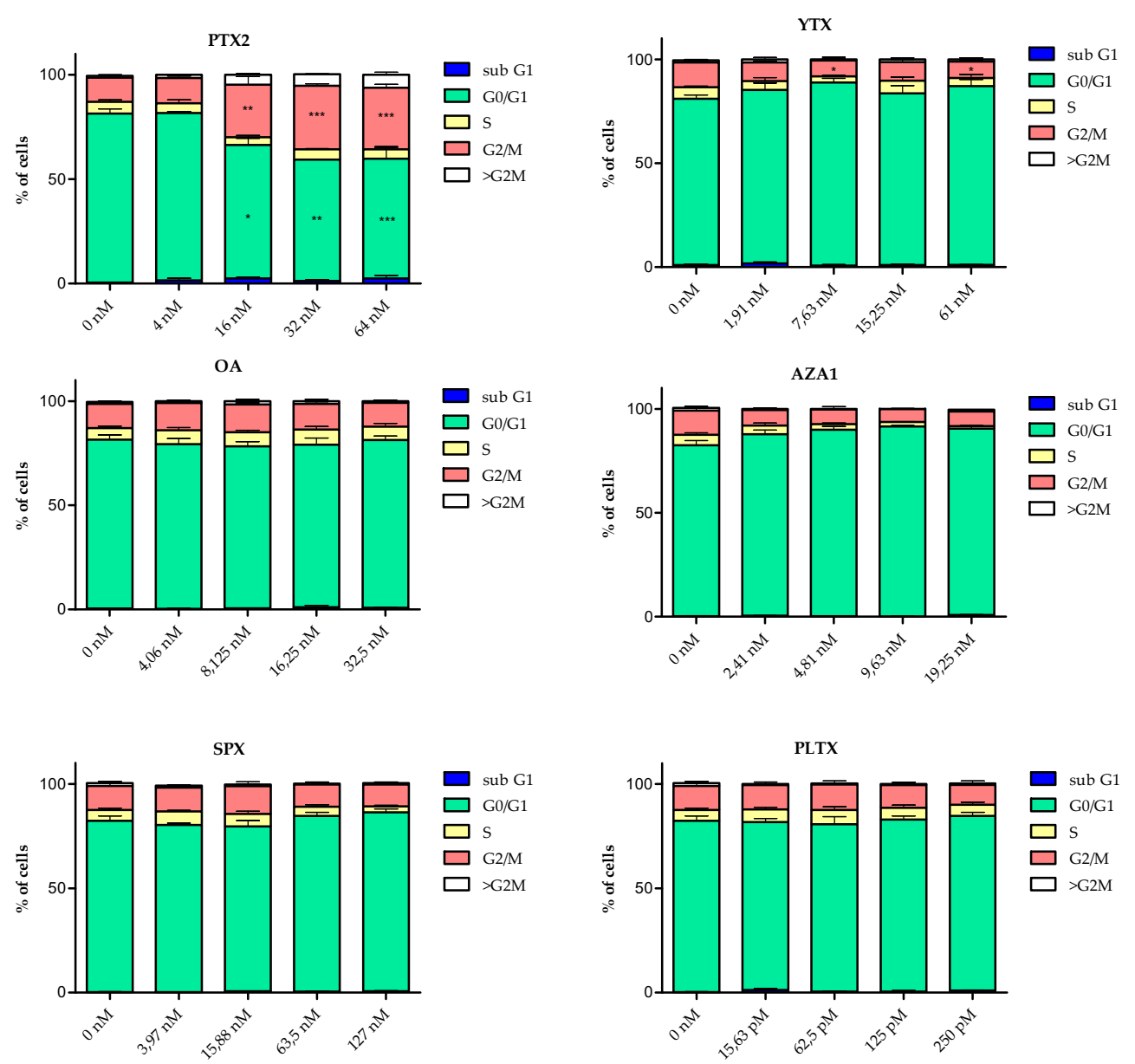

Figure 4. Cell cycle analysis of EGCs after $24 \mathrm{~h}$ exposure to PTX2, YTX, OA, AZA1, SPX, and PITX. The classification of cells in the different cell cycle phases was determined using nuclear DAPI labelling and is expressed relative to the percentage of cells in each phase. Values are presented as mean \pm SEM. Three independent experiments were performed. Vehicle controls were $1.25 \%$ of $\mathrm{MeOH}$ and $2.7 \%$ ultra-pure water (for PITX only). ${ }^{*}, * * * *$ : values significantly different from the vehicle control (respectively $P<0.05, P<0.01$ and $P<0.001$ ).

\subsection{Apoptosis and Genotoxicity}

A concentration-dependent increase of active caspase- 3 was observed for PTX2, YTX, and AZA1 (Figure 5). The maximum increase (between 1.6- and 1.8-fold) was similar for the 3 toxins but corresponded also to a 50\% decrease in cell count compared to the vehicle control (Figure 5). OA exposure significantly increased active caspase-3 level amounts only at the highest concentration. SPX and PITX did not affect the amount of caspase-3. The amount of $\gamma \mathrm{H} 2 \mathrm{AX}$ significantly increased at $16 \mathrm{nM}$ PTX2 (1.3-fold) reaching 1.5-fold at $64 \mathrm{nM}$. No effect on $\gamma \mathrm{H} 2 \mathrm{AX}$ levels was observed with the other toxins. 

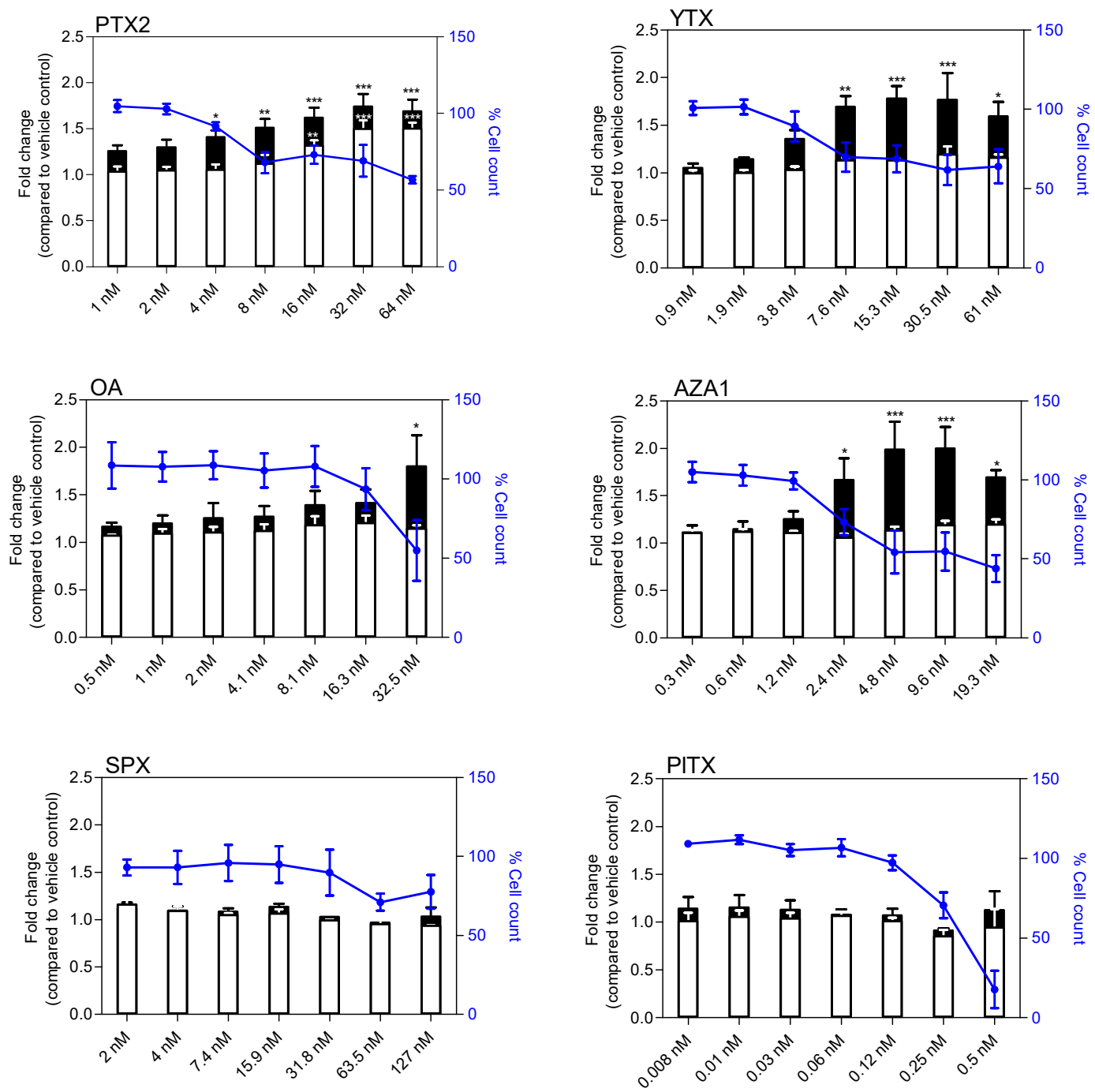

Figure 5. Apoptosis and genotoxicity in EGCs after $24 \mathrm{~h}$ exposure to PTX2, YTX, OA, AZA1, SPX, and PITX. Active caspase-3 (black) and $\gamma \mathrm{H} 2 \mathrm{AX}$ (white) were carried out by HCA. DAPI staining was used for cell count (blue). Active caspase- 3 and $\gamma \mathrm{H} 2 \mathrm{AX}$ are expressed as fold change compared to the vehicle control set to 1 . Cell count values are expressed as percentages of the vehicle control. Values are presented as mean \pm SEM. Three independent experiments were performed. ${ }^{*}, * *, * *$ : values significantly different from the vehicle control (respectively $P<0.05, P<0.01$, and $P<0.001$ ).

\subsection{NF- $\mathrm{B} B$ Nuclear Translocation}

No effect on NF-kB nuclear translocation was shown following $3 \mathrm{~h}$ treatment with YTX, OA, AZA1, SPX, and PITX (Figure 6A). With this short time treatment, no diminution of cell count was observed except with PITX (50\% decrease with $2 \mathrm{nM})$. However, for longer treatment times $(8 \mathrm{~h})$, a significant increase of NF-KB nuclear translocation was observed: up to 2-fold for YTX, 4-fold for OA, and 2.5-fold for AZA1 at the highest tested concentration. If no decrease of cell count was observed at $8 \mathrm{~h}$ for YTX and AZA1, a marked decrease was noticed following OA exposure.

For PTX2, nuclear translocation of NF-KB was ambiguous as rapid cell rounding was suspected resulting in quantification artefacts. Therefore, we further investigated the translocation of NF- $\mathrm{KB}$ at $3 \mathrm{~h}$ using confocal fluorescence microscopy. Contrary to the positive control $(50 \mathrm{ng} / \mathrm{mL} \mathrm{TNF} \alpha)$ that clearly showed nuclear translocation, no difference between PTX2 up to $64 \mathrm{nM}$ and the vehicle control was observed (Figure 6B). 

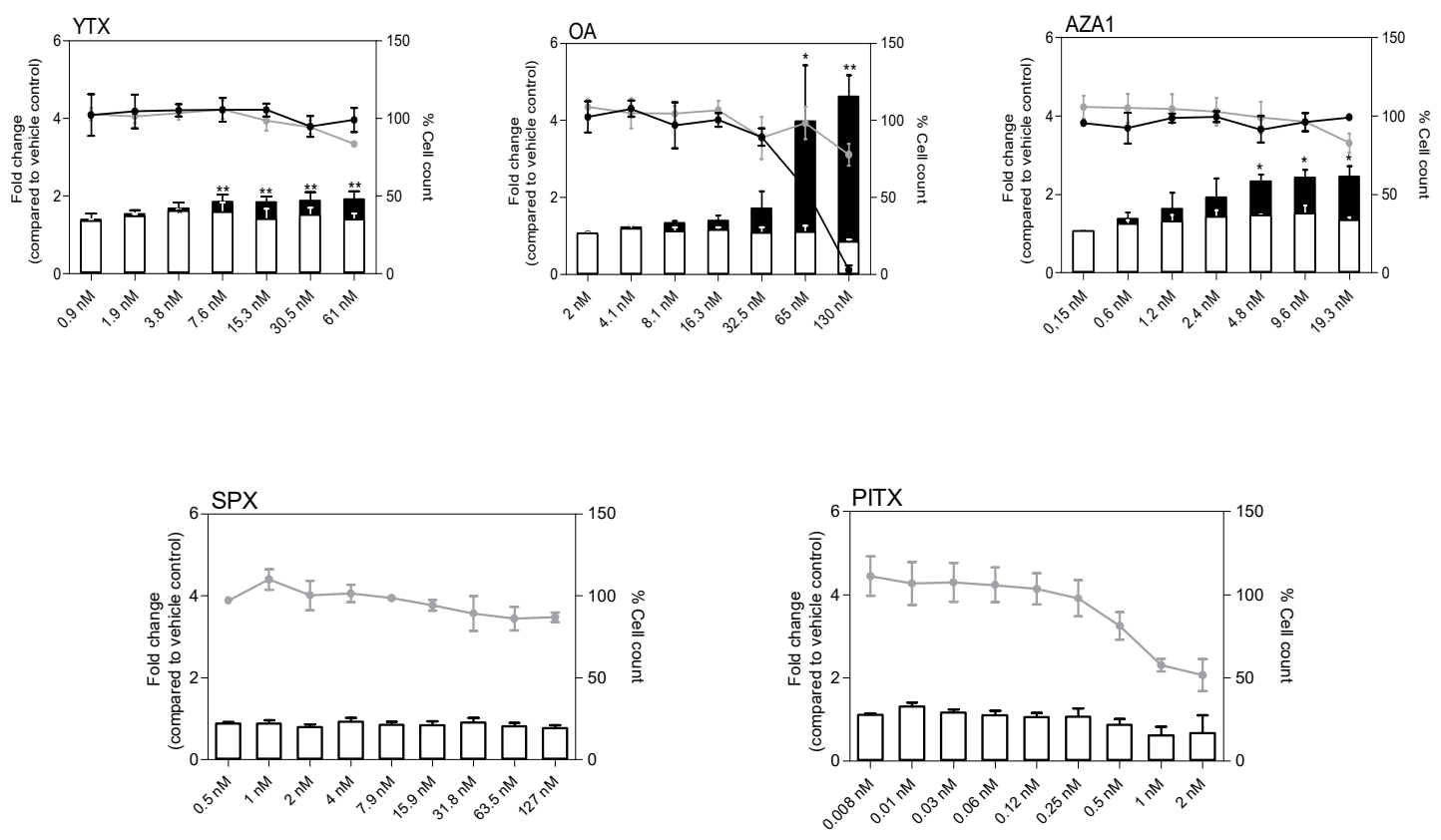

B


Figure 6. NF- $\mathrm{B}$ nuclear translocation in EGCs after exposure to PTX2, YTX, OA, AZA1, SPX, and PITX. (A) NF-kB-p65 nuclear translocation after $3 \mathrm{~h}$ (white) or $8 \mathrm{~h}$ (black) exposure was carried out by HCA. DAPI staining was used for cell count. NF-kB-p65 nuclear translocation was expressed as fold change compared to the vehicle control set to 1 . Cell count values after $3 \mathrm{~h}$ (grey line) or $8 \mathrm{~h}$ (black line) exposure are expressed as percentages of the vehicle control. Values are presented as means \pm SEM. Three independent experiments were performed. ${ }^{*}{ }^{* *}$ : values significantly different from the vehicle control (respectively $P<0.05$ and $P<0.01$ ). (B) NF-kB-p65 (red) and nucleus (blue) after 3 h exposure to TNF $\alpha(50 \mathrm{ng} / \mathrm{mL})$ and PTX2 $(64 \mathrm{nM})$ were observed by confocal imaging. Scale bar $=20 \mu \mathrm{m}$.

\subsection{Oxidative Stress}

At $4 \mathrm{~h}$ treatment, none of the toxins induced oxidative stress except PITX for which the increase (4-fold at $1 \mathrm{nM}$ ) was correlated with a decrease in cell count (Figure 7). At $24 \mathrm{~h}$ treatment, PTX2, YTX, and OA increased oxidative stress up to 3-, 1.8-, and 2-fold, respectively, at the highest concentration. A slight but non-significant increase was also noticed for AZA1 at $19.5 \mathrm{nM}$. Overall, oxidative stress was correlated to a decrease of cell count. SPX exposure up to $127 \mathrm{nM}$ did not induce oxidative stress in EGCs whatever the time and concentration of exposure. 

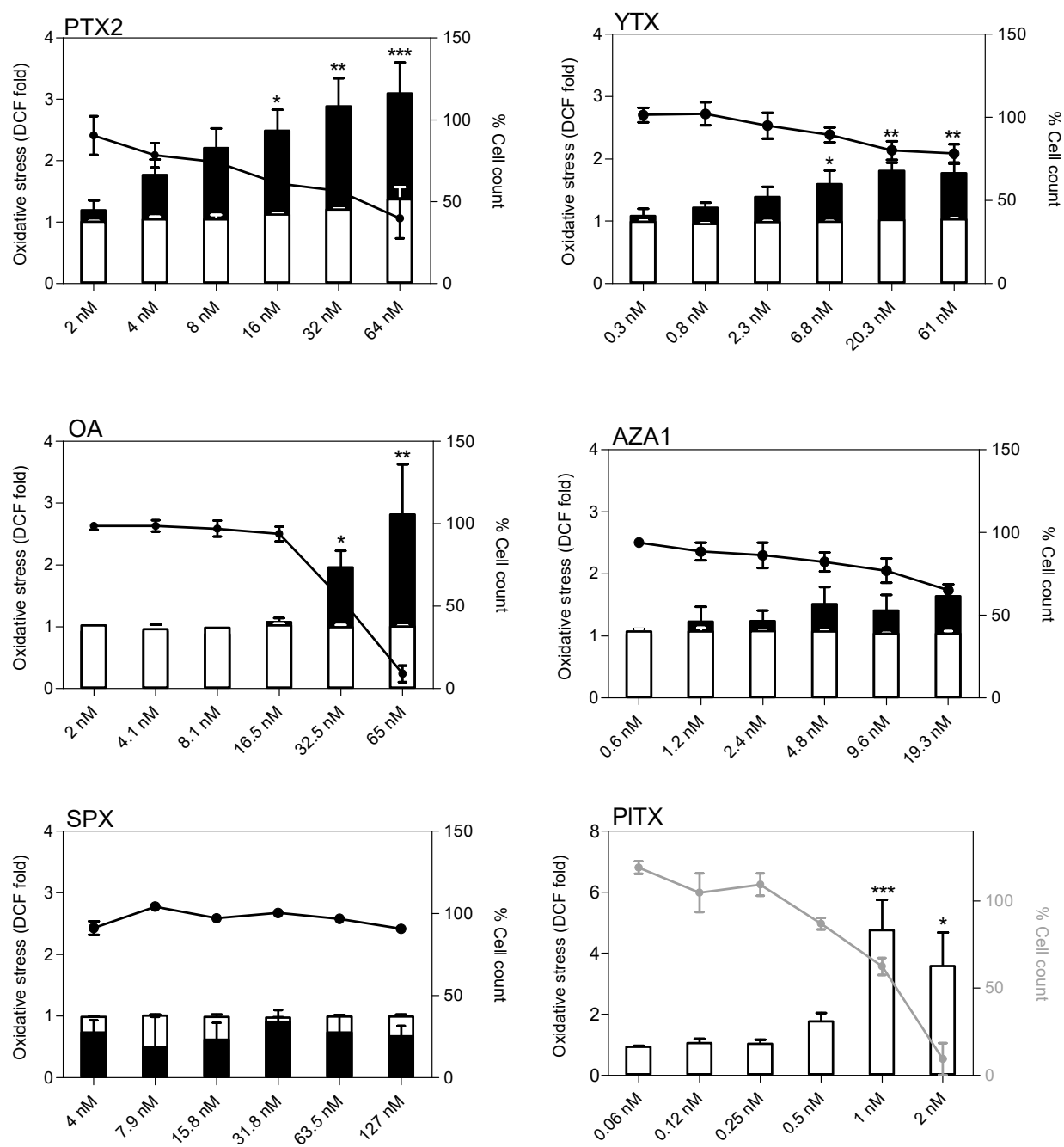

Figure 7. Oxidative stress in EGCs after exposure to PTX2, YTX, OA, AZA1, SPX, and PITX. Measurement of the fluorescent DCF product after $4 \mathrm{~h}$ (white) or $24 \mathrm{~h}$ (black) exposure was carried out by HCA. Hoescht staining was used for cell count. ROS production was expressed as fold change compared to the vehicle control set to 1 . Cell count values after $4 \mathrm{~h}$ (grey line) or $24 \mathrm{~h}$ (black line) exposure are expressed as percentages of the vehicle control. Values are presented as mean \pm SEM. Four independent experiments were performed. ${ }^{*}, * * * *$ : values significantly different from the vehicle control (respectively $P<0.05, P<0.01$, and $P<0.001$ ).

\subsection{S100ß and iNOS Production}

After $24 \mathrm{~h}$ treatment, a significant increase of S100 $\beta$ amount was observed with PTX2, YTX, OA, and AZA1 reaching 1.5-fold to 2.1-fold depending on the toxin and concomitantly with a decrease of cell count (Figure 8). No effect was detected with SPX and PITX, despite an important decrease of cell count for PITX at the highest concentration. The responses for iNOS amount were very similar to S100 $\beta$ for PTX2, YTX, OA, and AZA1 with increases reaching 1.5-fold to 2.2-fold depending on the toxin (Figure 9). iNOS levels were not affected by SPX and PITX. 


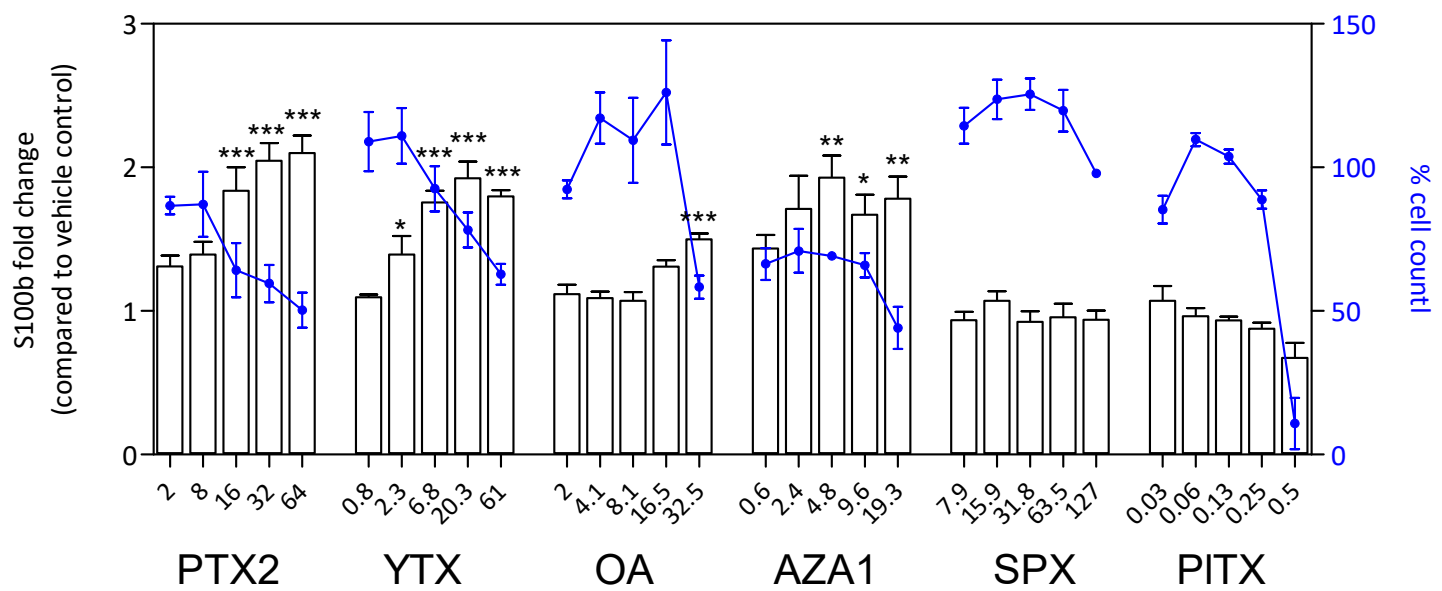

Figure 8. S100 $\beta$ response in EGCs after $24 \mathrm{~h}$ of phycotoxin exposure (nM). The measurement of S100 $\beta$ was carried out by HCA. DAPI staining was used for cell count (blue). S100 $\beta$ was expressed as fold change compared to the vehicle control set to 1 . Cell count values are expressed as percentages of the vehicle control. Values are presented as mean \pm SEM. Three independent experiments were performed. $*$, ****: significantly different from the vehicle control (respectively $P<0.05, P<0.01$, and $P<0.001$ ).

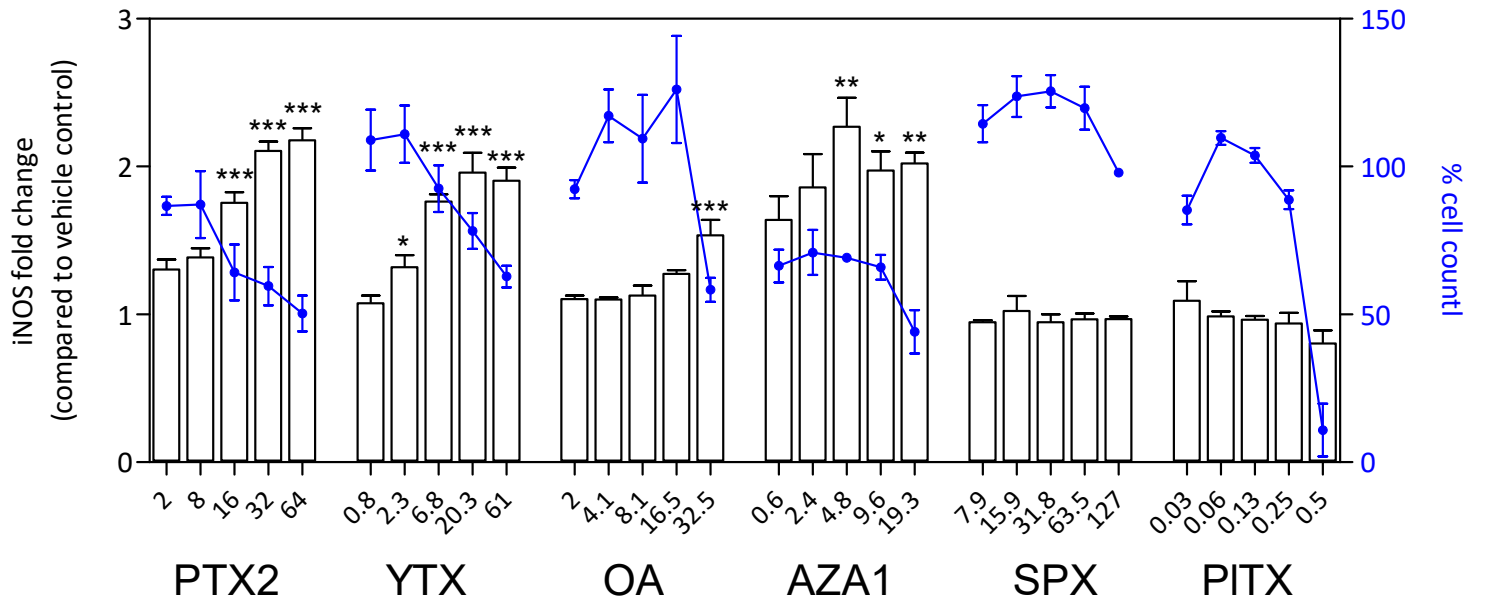

Figure 9. iNOS response in EGCs after $24 \mathrm{~h}$ of phycotoxin exposure (nM). The measurement of iNOS was carried out by HCA. DAPI staining was used for cell count (blue). iNOS was expressed as fold change compared to the vehicle control set to 1 . Cell count values are expressed as percentages of the vehicle control. Values are presented as mean \pm SEM. Three independent experiments were performed. $*, * * * * *$ : significantly different from the vehicle control (respectively $P<0.05, P<0.01$, and $P<0.001$ ).

\subsection{Modulation of Gene Expression Following Treatment with PTX2, YTX, and AZA1}

We selected the three toxins, PTX2, YTX, and AZA1, for additional investigation on the expression of key genes involved in viability, morphology, cell cycle, inflammation, oxidative stress, and gliomediators. Table 1 presents only the statistically significant results and the whole dataset is included as supplementary information (Supplementary Materials Table S2). An up-regulation of genes associated with cell mortality was observed with a 1.6-fold increase of BNIP3 at $2 \mathrm{nM}$ YTX and $1.5 \mathrm{nM}$ AZA1, and 1.6-fold increase of GABARAP at 1.5 nM AZA1. CASP3 was significantly decreased with PTX2 at the highest dose $(-52 \%$ at $4 \mathrm{nM})$. FOS, a gene involved in apoptotic response, was increased at the highest concentration for YTX and AZA1. Complementary to FOS, BCL2 was decreased for YTX at the highest concentration. The expression of cell cycle genes was significantly affected by two toxins. YTX induced decreases in CDK1 $(-78 \%)$, CDK2 $(-42 \%)$, and CCNA2 $(-77 \%)$ expression at the highest concentration. Similarly, AZA1 (at $1.5 \mathrm{nM})$ induced a down regulation of CDK1 $(-66 \%)$, CDK2 $(-27 \%)$, and CCNA2 $(-57 \%)$. PTX2 induced a trend of decrease for CDK1 gene 
expression at $4 \mathrm{nM}$. Modification of the expression of genes involved in inflammation was observed with the 3 toxins. PTX2 significantly induced an up regulation of 1.4-fold of MAPK8 and MYD88 expression, respectively, at $2 \mathrm{nM}$ and $4 \mathrm{nM}$. YTX induced a significant increase of chemokine CCL2 (up to 2.2-fold at $2 \mathrm{nM}$ ) as well as significant down regulations of receptor IL1R1 ( $-53 \%$ at $4 \mathrm{nM}$ ), RHOA $(-22 \%$ at $2 \mathrm{nM})$, and FZD4, an anti-inflammatory signaling receptor, $(-59 \%)$. AZA1 induced a significant increase of MAPK8 (1.5-fold at $0.38 \mathrm{nM}$ ), CCL2 (up to 2.5-fold at $1.5 \mathrm{nM}$ ), and TLR4 (1.8-fold at $1.5 \mathrm{nM})$. For genes related to oxidative stress, PTX2 induced a decrease of CAT expression $(-25 \%$ at $4 \mathrm{nM}$ ), while AZA1 induced a significant increase of NFE2L2 (1.5-fold at $1.5 \mathrm{nM})$. Exposure to PTX2 resulted in the up regulation of gliomediator genes: BDNF and GNDF expression increased up to 5.2 and 2.7-fold, respectively, at the highest concentration, although this was not statistically significant. YTX induced a significant 1.5-fold increase of GDNF. For channel and glioreceptor genes, our results showed a 50\% decrease of GJA1 with 4 nM YTX. GFRA1 expression, a receptor of GDNF, was 1.4-fold increased with $2 \mathrm{nM}$ PTX2, 1.3-fold with $4 \mathrm{nM}$ YTX, and 1.4-fold with $0.38 \mathrm{nM}$ AZA1. LPA1, a gene coding for adrenergic receptor, was increased up to 1.7-fold with 4 nM PTX2.

Table 1. Gene expression in EGCs after 24 h exposure to PTX2, YTX, and AZA1. The analysis of gene expression was carried out by RT-qPCR. The resulting fold changes were calculated normalized to the reference gene GAPDH and the solvent-treated control. The heatmap shows the relative fold change values (red: up regulated and blue: down regulated) as well as statistical analysis of three independent experiments. ${ }^{*}{ }^{* *},{ }^{* * *}$ : significantly different from the vehicle control (respectively $P<0.05, P<0.01$, and $P<0.001)$. ${ }^{\text {a }}$ : significant concentration effect $(P<0.05)$.

0.2

1

6

\begin{tabular}{|c|c|c|c|c|c|c|c|c|c|c|}
\hline \multirow{2}{*}{ Biological Function } & \multirow[b]{2}{*}{ Gene } & \multicolumn{3}{|c|}{ PTX2 (nM) } & \multicolumn{3}{|c|}{ YTX (nM) } & \multicolumn{3}{|c|}{ AZA1 (nM) } \\
\hline & & 1 & 2 & 4 & 1 & 2 & 4 & 0.38 & 0.75 & 1.5 \\
\hline \multirow{5}{*}{ Viability } & $\overline{B N I P 3}$ & & & & & ** & & & & * \\
\hline & CASP3 & & & $* * *$ & & & & & & \\
\hline & GABARAP & & & & & & & & & * \\
\hline & FOS & & & & & * & * & & * & * \\
\hline & $B C L 2$ & & & & & & * & & & \\
\hline Morphology & GFAP & $\mathrm{a}$ & $\mathrm{a}$ & $\bar{a}$ & & & & & & 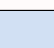 \\
\hline \multirow{3}{*}{ Cell cycle } & $C D K 1$ & & & & * & $* * *$ & $* * *$ & & * & ** \\
\hline & $C D K 2$ & & & & & $*$ & $* *$ & & $* *$ & $* *$ \\
\hline & CCNA2 & & & & ** & $* * *$ & $* * *$ & & & * \\
\hline \multirow{7}{*}{ Inflammation } & IL1R1 & & & & & & ** & & & \\
\hline & MAPK 8 & & * & & & & & * & & 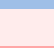 \\
\hline & CCL2 & & & & & $*$ & & & * & * \\
\hline & MYD88 & & & ** & & & & & & \\
\hline & RHOA & & & & & & * & & & \\
\hline & TLR4 & & & & & & & & & * \\
\hline & FZD4 & & & & & & * & & & \\
\hline \multirow[b]{2}{*}{ Oxidative stress } & CAT & & & & & & & & & \\
\hline & NFE2L2 & & & & & & & & & ** \\
\hline \multirow{2}{*}{ Gliomediator } & $B D N F$ & & & & & & & & & \\
\hline & GDNF & & & & & & * & & & \\
\hline \multirow[b]{2}{*}{$\begin{array}{l}\text { Channel and } \\
\text { receptor }\end{array}$} & GJA1 & & & & & & $* *$ & & & \\
\hline & $\begin{array}{c}\text { GFRA1 } \\
\text { LPA1 }\end{array}$ & & * & * & * & & $*$ & * & * & * \\
\hline
\end{tabular}

\section{Discussion}

Our results show that PTX2, YTX, OA, AZA1, and PITX cause morphological alterations of EGCs, particularly through disturbance of the neurite network, suggesting that communication between glial cells and other cell types may be affected. Indeed, the network of neurites is highly involved in several 
interactions, such as binding and transmission of mediators [33,40]. Similar to the morphological alterations observed in EGCs, PTX2, YTX, OA, AZA1, and PITX have previously been shown to disrupt the cytoskeleton in various mammalian cells through the disturbance of F-actin network in different cell types $[38,41-46]$. As observed in our study, AZA1 was previously shown to decrease the number of neurites in BE(2)-M17 cells [47] and induced an irreversible neurite rearrangement in mouse primary neurons after $48 \mathrm{~h}$ of treatment [48]. Similarly to our result, no cytoskeletal alterations have been observed with SPX on various cell lines [49]. Among the five toxins, only PTX2 induced a decrease of cell body area in EGCs without any effect on cell viability. Similar observations were reported with PTX2 on an epithelial rat liver cell line (Clone 9) at $24 \mathrm{~h}$ treatment [50]. The morphological changes of EGCs were consistent with variations in GFAP levels, an intermediate filament protein as a key marker of glial cell morphology. As a hallmark feature of glial stress, GFAP level is increased by cell injuries and its level correlates with the functional state of EGCs [31,51]. A decrease of GFAP intensity was observed with PITX, which could be a consequence of the increase of body cell area through blebbing as the increase of cellular area would lead to a decrease of the GFAP intensity per $\mathrm{cm}^{2}$.

No significant modifications were observed with PTX2, YTX, and AZA1 for calpain genes (CAPN1 and CAPN2), a protease involved in GFAP degradation, which reinforces the hypothesis that GFAP was not adversely affected. Interestingly, gene expression analysis indicated no significant modifications for GFAP except a slight decrease with PTX2. However, the discrepancy between gene expression and protein staining could be related to the slow turn-over of GFAP in glial cells (in vitro half-life of 3-4 days) [52,53], which may explain why we did not observe any decrease of GFAP protein with PTX2. It is noteworthy that a GFAP increase was observed in inflamed regions of the intestine $[51,54,55]$ and that cytokine stimulation could control GFAP up-regulation in enteric glial cells [51].

In agreement with our results, intestinal inflammation has been induced by various phycotoxins: presence of infiltrated lymphocytes detected in the gut submucosa of mice after YTX exposure [56], the presence of neutrophils in the lamina propria [19] as well as infiltration of inflammatory cells in lung and liver [20] described with AZA1 and induction of an inflammatory response with OA and AZA1 in various cell lines $[22,57,58]$.

Besides, NF-KB nuclear translocation, a transcription factor involved in the inflammatory response [59], as well as expression of inflammation genes were induced in EGCs with YTX and AZA1. As reported by Nezami et al., abdominal pain is a manifestation of inflammation of the enteric nervous system due to the secretion of inflammatory cytokines and mediators [60]. Therefore, the pain observed after OA and AZA1 intoxication could be related to an inflammatory response. Although PTX2 did not affect NF- $\mathrm{KB}$ translocation as previously reported [61], a significant increase in the expression of genes involved in inflammatory processes were observed, suggesting that PTX2 might induce inflammation through another pathway than NF-kB.

In addition, our data showed that toxins can alter key functions of EGCs as both $\mathrm{S100} \beta$ and iNOS levels were increased concomitantly after OA, PTX2, YTX, and AZA1 exposure. S100 $\beta$, which is induced by activation of the RAGE receptor and MyD88 protein [31], was described to enhance iNOS expression $[62,63]$ and lead to inflammation through the NF- $\mathrm{kB}$ pathway $[62,64,65]$, induction of cytoskeletal modifications [66,67], and apoptosis [68]. Up regulation of S100 $\beta$ was described as an adaptive response to the stress of EGCs [63]. iNOS also acts as an inflammation mediator [69-71]. Furthermore, the production of iNOS contributes to glial dysfunctions, increasing oxidative stress [72-74]. While our study is the first one exploring S100 $\beta$ and iNOS responses after phycotoxin exposure, Franchini et al. previously observed an increase of S100 protein in Purkinje cells after an intraperitoneal injection of YTX [75].

Our data revealed that PTX2, YTX, OA, and AZA1 induced apoptosis in EGCs supported by the activation of caspase- 3 and the increase of subG1 cells, particularly for PTX2. Caspase-3 activation has been described in other mammalian cells with PTX2 [76], YTX [77,78], OA [47,79,80], and AZA1 [81,82]. Nevertheless, the level of $\gamma \mathrm{H} 2 \mathrm{AX}$, a marker of DNA double strand breaks, was induced only with PTX2. Shin et al. (2011) have previously shown that PTX2 induced apoptosis and DNA breaks following actin 
disruption in MCF-7 cells [83]. We suggest that apoptosis occurred later with YTX, OA, and AZA1, or that DNA repair was more efficient. A slight decrease of cells in G2/M combined with a slight increase of cells in G0/G1 was induced with YTX that could be a reflection that cells were entering into a repairing state. Although DNA repair involvement has been shown with OA [84] and YTX [85], further investigation is needed to explain these differences.

In addition to a subG1 increase, PTX2 induced an arrest of EGCs in G2/M and an increase of polyploid cells. The G2/M blockage by PTX2 has been reported with other mammalian cells $[86,87]$ and it has been proposed to be a consequence of the disturbance of actin polymerization [88]. Frizzo et al. have reported that a large amount of $S 100 \beta$ can inhibit microtubule elongation, causing a rapid disassembly and cell cycle perturbations [67]. Therefore, the increased levels of S100 $\beta$ observed with PTX2 could be linked to G2/M arrest.

Previous studies have shown that the production of iNOS induces oxidative stress by NO production [72-74]. NO production results in apoptosis, mitochondrial respiration failure, and glial degeneration mediated through covalent S-nitrosylation of proteins that affect their activities. The level of oxidative stress was significantly increased in PTX2-, YTX-, OA-, and AZA1-treated EGCs. In agreement with our results, PTX2, YTX, and OA were shown to increase ROS production described in a variety of mammalians cell lines [89-93]. Although AZA1 induced some oxidative stress in EGCs (not statistically-significant), Vale and Hjornevik did not report ROS production in rat PC12 cell line and in primary cultures of cerebellar granule cells with AZA1 [94,95]. To summarize, our observations in EGCs suggest the involvement of the S100 $\beta$-iNOS-oxidative stress pathway in EGCs following PTX2, YTX, OA, and AZA1 exposure.

Gliomediators such as GDNF and BDNF produced by EGCs are involved in preserving intact epithelial lining and promoting regeneration of IECs $[96,97]$. We observed that PTX2 and YTX treatment increased the expression of some gliomediator genes, but this observation should be confirmed at the protein level. As previously described [98,99], the increase of GDNF and BDNF gene expression with PTX2 and YTX seems to be a protective response of EGCs in order to counteract the increased caspase-3, S100 $\beta$, and iNOS levels [100]. Indeed, GDNF and BDNF are known as important endogenous factors for the regulation of apoptosis in EGC cells $[98,99]$. Although we did not investigate the effects of $\mathrm{OA}$ on the expression of gliomediators, Louzao et al. reported the capacity of OA to induce the neuropeptide Y (NPY) in SH-SY5Y neuroblastoma cells [38]. NPY inhibits electrolyte secretion and is promoted by GDNF in the enteric nervous system [101].

In contrast to these four toxins, PITX did not show any increase of active caspase- $3, \gamma \mathrm{H} 2 \mathrm{AX}, \mathrm{S} 100 \beta$, iNOS, nuclear translocation of NF-kB, nor modifications of the cell cycle in EGCs. Previous studies have already pointed out the absence of caspase activation but rather the induction of the cell death in a necrosis-like manner by PITX in various cells [44]. The rapid cell death of EGCs (beginning at $3 \mathrm{~h}$ of exposure) and the increase of cell body area with PITX are in favor of a necrotic process. Disturbance of ion flux by PITX [21] provokes a change of osmotic pressure and an increase of the cytoplasmic area leading to necrosis [14,102]. As PITX did not increase glial specific markers, early oxidative stress may be induced independently of the S100 $\beta$-iNOS pathway. The early ROS production is probably not cell-type dependent since Pelin et al. have observed the same response in human keratinocytes [103].

Among the six toxins tested in our study, SPX showed a distinct lack of response on EGCs as none of the endpoints investigated was affected by SPX exposure. The absence of cytotoxicity by SPX was also reported using a large range of cell lines [49]. SPX is documented to inhibit both muscarinic (mAChr) and nicotinic acetylcholine receptors (nAChr) [104]. Recent studies showed that EGCs support enteric neurons through the expression of a large number of neurotransmitter receptors, such as mAChr [33,101], especially both M3 and M5 subtypes [105]. Although SPX induced the inhibition of M3 mAChr, it did not alter the level of M3 mAChR protein, and its toxicity seems mainly mediated by nicotinic rather than muscarinic AChR $[106,107]$. These observations strengthen the absence of effects of SPX on EGCs in our study but did not exclude that effects on enteric neurons could occur and then affect neurotransmission, for example. 
We have highlighted that each toxin induced a different response in EGCs, as described in previous studies, evoking singular mechanisms of action [22,108]. Table 2 summarizes the results obtained in EGCs and illustrates the complexity of toxicological responses induced by each toxin. Figure 10 resumes our observations on EGCs for each toxin and highlights which effects are common or specific. PTX2, YTX, OA, and AZA1 globally induced the same effects on EGCs but only PTX2 activated the gliomediators expression. Instead of the other toxins, SPX did not impact EGCs while PITX induced a rapid cytotoxicity.

\section{Materials and Methods}

\subsection{Chemicals}

Penicillin, streptomycin, fetal bovine serum (FBS), and Dulbecco's Modified Eagle's Medium with high glucose (DMEM) were purchased from Gibco (Cergy-Pontoise, France). Bovine serum albumin (BSA), Tween 20, Triton X-100, and neutral red were supplied by Sigma-Aldrich (Saint Quentin Fallavier, France). OA, PTX2, YTX, AZA1, and SPX were purchased from the National Research Council Canada (Halifax, NS, Canada) and were dissolved in methanol (MeOH). PITX was supplied by Wako Chemicals GmbH (Neuss, Germany) and dissolved in ultra-pure sterile water.

\subsection{Cell Culture and Toxin Exposure}

The rat enteric glial cell line (EGC) (CRL2690) was obtained from the American Type Culture Collection (Manasas, VA, USA). Cells were grown in DMEM supplemented with 10\% FBS, $50 \mathrm{IU} / \mathrm{mL}$ penicillin, and $50 \mu \mathrm{g} / \mathrm{mL}$ streptomycin at $37{ }^{\circ} \mathrm{C}$ and $5 \% \mathrm{CO}_{2}$. Cells were used at passages from 38 to 58 . For subculture, cells were seeded in $75 \mathrm{~cm}^{2}$ culture flasks and passaged twice a week. For experiments, cells were seeded at $30,000 \mathrm{cells} / \mathrm{cm}^{2}$ in 96 -well plates for cytotoxicity and HCA assays, and at $40,000 \mathrm{cells} / \mathrm{cm}^{2}$ in 12 -well plates for qPCR assay. The day after seeding, cells were exposed to toxins in FBS free medium. Two vehicle controls (2.7\% sterile water for PITX, 1.25\% $\mathrm{MeOH}$ for the other toxins) were included in each experiment.

\subsection{Cell Morphology and Neutral Red Uptake Assay}

After $24 \mathrm{~h}$ of treatment with toxins, cell morphological changes were observed by phase contrast microscopy (Leica Microsystems, Wetzlar, Germany), and the neutral red uptake (NRU) assay was performed as previously described [22]. Absorbance was measured at $540 \mathrm{~nm}$ with a microplate reading spectrofluorometer (Fluostar OPTIMA, BMG Labtech, Champigny sur Marne, France). Three independent experiments were performed, and for each experiment, the median of the three technical replicates was expressed relative to that of the vehicle control. When possible, the $\mathrm{IC}_{50}$ was determined using GraphPad Prism Software (La Jolla, CA, USA).

\subsection{High Content Analysis Multiparametric Toxicity Assays Oxidative Stress}

After 4 and $24 \mathrm{~h}$ of toxin treatment, cells were incubated at $37{ }^{\circ} \mathrm{C}$ for $60 \mathrm{~min}$ with $10 \mu \mathrm{M}$ CM- $\mathrm{H}_{2}$ DCFDA (Thermo Scientific, Waltham, MA, USA) in DMEM, and then for 10 min with $3 \mu \mathrm{g} / \mathrm{mL}$ Hoescht 33,342 (Sigma-Aldrich) in DMEM. Fluorescence was monitored with an Arrayscan VTI HCS Reader (Thermo Scientific) associated with a live cell chamber. The Target Activation module of the BioApplication software was used to quantify the oxidized DCF in the cytoplasm. Cell count was performed using Hoescht labelling. Hydrogen peroxide $\left(\mathrm{H}_{2} \mathrm{O}_{2}\right)(70 \mu \mathrm{M}$, Gifrer Barbezat, Decines, France) was used as the positive control. Four independent experiments were performed, and for each experiment, the average intensity of the three technical replicates was expressed relative to that of the vehicle control. 
Table 2. Summary of in vitro toxicity of six phycotoxins on the rat EGC cell line CRL2690. Cell viability, morphological cell changes, oxidative stress, inflammation, cell cycle, and gliomediator expression were evaluated using RT-qPCR and high content analysis (HCA) approaches. n.e.: no effect. +, ++, +++: low, moderate, and high effect, respectively. n.t.: not tested.

\begin{tabular}{|c|c|c|c|c|c|c|c|c|c|c|c|}
\hline \multirow[t]{2}{*}{ Toxins } & \multicolumn{2}{|c|}{ MORPHOLOGY } & \multicolumn{3}{|c|}{ VIABILITY } & \multirow{2}{*}{$\begin{array}{c}\text { CELL } \\
\text { CYCLE } \\
\text { Phases }\end{array}$} & \multirow{2}{*}{$\begin{array}{c}\text { OXIDATIVE } \\
\text { STRESS } \\
\text { Oxidative Marker }\end{array}$} & \multicolumn{2}{|c|}{ INFLAMMATION } & \multicolumn{2}{|c|}{ GLIOMEDIATORS } \\
\hline & Microscopy & GFAP & $\mathrm{IC}_{50}(\mathrm{nM})$ & Caspase-3 & $\gamma \mathrm{H} 2 \mathrm{AX}$ & & & NF-KB & $S 100 \beta$ & iNOS & Gliomediator Genes \\
\hline PTX2 & $\begin{array}{l}\text { neurites } \\
\text { alteration }\end{array}$ & ++ & n.e. & ++ & ++ & $\begin{array}{l}\operatorname{subG}_{1} \nearrow \\
\mathrm{G}_{2} / \mathrm{M} \nearrow\end{array}$ & $\begin{array}{c}+++ \\
(24 \mathrm{~h})\end{array}$ & $\begin{array}{l}\text { n.e. } \\
(3 \mathrm{~h})\end{array}$ & ++ & ++ & $\begin{array}{l}\text { BDNF } \nearrow \\
\text { GDNF } \nearrow\end{array}$ \\
\hline YTX & $\begin{array}{l}\text { neurites } \\
\text { alteration }\end{array}$ & ++ & 14.5 & ++ & n.e. & $\begin{array}{l}\operatorname{subG}_{1} \nearrow \\
\mathrm{G}_{2} / \mathrm{M} \searrow\end{array}$ & $\begin{array}{c}++ \\
(24 \mathrm{~h})\end{array}$ & $\begin{array}{c}+ \\
(8 \mathrm{~h})\end{array}$ & ++ & ++ & GDNF $\nearrow$ \\
\hline OA & $\begin{array}{c}\text { cell } \\
\text { rounding }\end{array}$ & + & 75.9 & + & n.e. & $\operatorname{subG}_{1} \nearrow$ & $\begin{array}{c}+ \\
(24 \mathrm{~h})\end{array}$ & $\begin{array}{c}++ \\
(8 \mathrm{~h})\end{array}$ & + & + & n.t. \\
\hline AZA1 & $\begin{array}{l}\text { neurites } \\
\text { alteration }\end{array}$ & ++ & 7.0 & ++ & n.e. & $\begin{array}{l}\operatorname{subG}_{1} \nearrow \\
\mathrm{G}_{2} / \mathrm{M} \searrow\end{array}$ & $\begin{array}{c}+ \\
(24 \mathrm{~h})\end{array}$ & $\begin{array}{c}++ \\
(8 \mathrm{~h})\end{array}$ & ++ & ++ & n.e. \\
\hline SPX & n.e & n.e. & n.e. & n.e. & n.e. & n.e. & n.e. & $\begin{array}{l}\text { n.e. } \\
(3 \mathrm{~h})\end{array}$ & n.e. & n.e. & n.t. \\
\hline PITX & blebbing & - & 0.4 & n.e. & n.e. & n.e. & $\begin{array}{c}++ \\
(4 \mathrm{~h})\end{array}$ & $\begin{array}{l}\text { n.e. } \\
(3 \mathrm{~h})\end{array}$ & n.e. & n.e. & n.t. \\
\hline
\end{tabular}




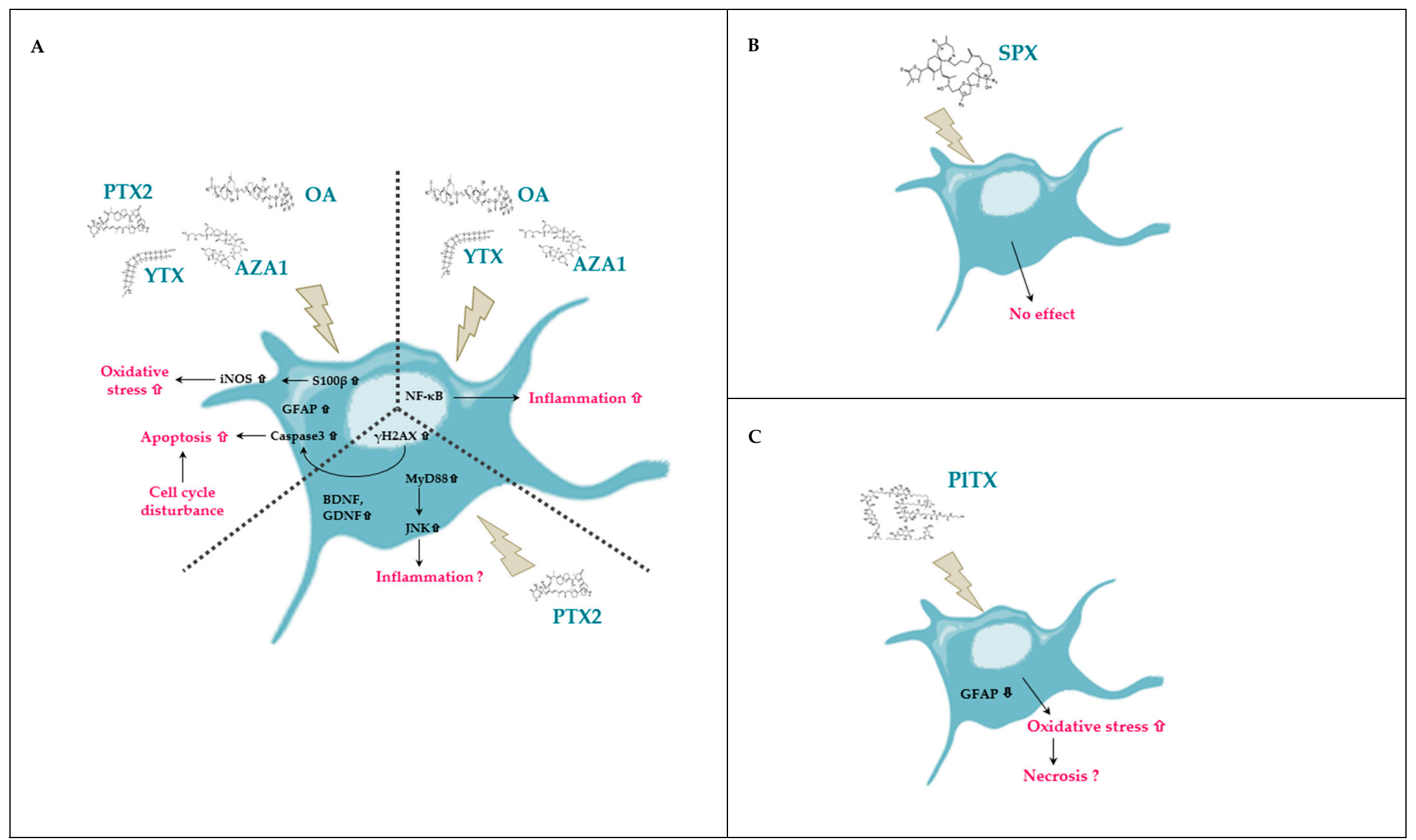

Figure 10. Schematic representation of the effects of PTX2, YTX, OA, AZA1, SPX, and PITX induced on the rat EGC cell line CRL2690 illustrating the common and unique responses of each toxin. (A) Common effects and unique effects of PTX2, YTX, OA, and AZA1 on EGCs. (B) Effects of SPX on EGCs. (C) Effects of PITX on EGCs. 


\subsection{Cell Cycle Analysis, Inflammation, Genotoxicity, Apoptosis, and Glial Cell Markers}

The immunofluorescence detection of the different markers was performed as previously described [109] with the following modifications. Antibodies were purchased from Abcam (Cambridge, UK) and BD Pharmingen Biosciences (Franklin Lakes, NJ, USA), and diluted as follows: mouse anti-GFAP (1/100, BD-556328), rabbit anti-active caspase-3 (1/1000, ab13847), mouse anti- $\gamma \mathrm{H} 2 \mathrm{AX}$ ser139 (1/1000, ab26350), rabbit anti-NF-kB-p65 (1/1000, ab16502), rabbit anti-S100 $\beta$ (1/350, ab52642), mouse anti-iNOS (1/350, ab49999), goat anti-mouse IgG H\&L Alexa Fluor ${ }^{\circledR} 555$ (1/1000, ab150114), and goat anti-rabbit IgG (H\&L) Alexa Fluor ${ }^{\circledR} 647$ (1/1000, ab150079). Labeling was performed after $24 \mathrm{~h}$ of treatment with the toxins except for NF-kB, for which a shorter time of exposure ( 3 and $8 \mathrm{~h}$ ) was chosen.

Cells were classified in the different cell cycle phases through DAPI (Sigma-Aldrich) labelling using the Cell Cycle Analysis module of the BioApplication software. Results were expressed relative to the total cell number. Cytochalasin B $\left(4.5 \mu \mathrm{g} / \mathrm{mL}\right.$, Sigma-Aldrich) was used as the control for $\mathrm{G}_{2} / \mathrm{M}$ phase calibration. The Target Activation module of the BioApplication software was used to quantify $\gamma \mathrm{H} 2 \mathrm{AX}$ (DNA double strand breaks) in the nucleus, and active caspase-3 (apoptosis), iNOS, and S100 $\beta$ (glial cell markers) in the cytoplasm. Methylmethanesulfonate (MMS $400 \mu \mathrm{M}$, Acros Organics, Fairlawn, NJ, USA) and cytomix (50 ng/mL TNF $\alpha$ (BD Pharmingen Biosciences) $+50 \mathrm{ng} / \mathrm{mL}$ Il1 $\beta$ (Sigma-Aldrich) $+50 \mathrm{ng} / \mathrm{mL}$ IFN- $\gamma$ (Thermo Fisher, Walthan, MA, USA)) were used as positive controls for $\gamma \mathrm{H} 2 \mathrm{AX}$ and iNOS, respectively.

NF-KB-p65 nuclear translocation was analyzed using the Compartmental Analysis module. TNF $\alpha$ $(50 \mathrm{pg} / \mathrm{mL})$ was used as a positive control. Intermediate filament GFAP was described as a key marker of glial cell functions [63]. The Neurite Detection module was used to quantify both GFAP in the cytoplasm and body cell area.

For each well, 8 fields (20× magnification) were analyzed. Cell counts were performed using nuclear DAPI labelling. Three independent experiments were performed and, for each experiment, the median intensity of three technical replicates was expressed relative to that of the vehicle control. For NF-kB-p65 nuclear translocation, the (nuclear-cytoplasm) difference of intensity was determined and expressed relative to that of the vehicle control.

\subsection{Confocal Microscopy Imaging}

After $3 \mathrm{~h}$ of treatment with $64 \mathrm{nM}$ PTX2, immunostaining of NF-kB-unit p65 was performed as described above. Analysis was performed using an inverted laser-scanning confocal microscope SP8 DMI 6000 CS (Leica Microsystems, Wetzlar, Germany). Images were analyzed with the LAS AF 3.3.0.10134 software (Leica Microsystems, Wetzlar, Germany) and assembled using the ImageJ software.

\section{7. $R T-q P C R$}

After $24 \mathrm{~h}$ of treatment with PTX2 (1, 2, and $4 \mathrm{nM})$, YTX (1, 2, and $4 \mathrm{nM})$, and AZA1 $(0.38,0.75$, and $1.5 \mathrm{nM}$ ) (dose corresponding at the $\mathrm{IC}_{20}$ ), total RNA was isolated, quantified, and assessed for integrity as previously described [110]. A negative extraction control was included for contamination assessment. Reverse transcription (RT) was performed with $1 \mu \mathrm{g}$ of total RNA using the Transcriptor Universal cDNA Master kit (Roche, Mannheim, Germany) according to the manufacturer's instructions. Reaction volume was set to $20 \mu \mathrm{L}$ and RT was performed at $55^{\circ} \mathrm{C}$ for $10 \mathrm{~min}$ prior to a stopping step for $5 \mathrm{~min}$ at $85{ }^{\circ} \mathrm{C}$. Negative RT control of RNase-free water and a no-reverse transcription control (replacement of reverse transcriptase by RNase-free water) were included for assessing, respectively, external contamination and absence of DNA occurring during RNA extraction. The sequences of targeted genes were obtained from the National Center for Biotechnology Information GenBank sequence database (https://www.ncbi.nlm.nih.gov/). For primers, design and in silico analyses for their specificity were performed together using the Primer Basic Local Alignment Search Tool (http://www.ncbi.nlm.nih.gov/tools/primer-blast) with, for each gene, at least one primer designed on an exon-exon junction when possible. All primers were purchased from Sigma-Aldrich. Additional 
information on target genes and oligonucleotide primers are listed in Supplementary Materials Table S1. Quantitative PCR was performed with a LightCycler ${ }^{\circledR} 480$ (Roche) in 384-well plates. Reactions were carried out on two technical replicates in a total volume of $5 \mu \mathrm{L}$ containing 1 X LightCycler 480 SYBRGreen I Master (Roche), $300 \mathrm{nM}$ of each primer, and 2.5, 0.6, or $0.2 \mathrm{ng}$ cDNA, depending of the target gene. Negative quantitative PCR controls of RNase-free water were included in each run for contamination assessment. The thermal cycling conditions were $95^{\circ} \mathrm{C}$ for $5 \mathrm{~min}$, followed by 45 amplification cycles of denaturation at $95{ }^{\circ} \mathrm{C}$ for $10 \mathrm{~s}$, annealing at $60{ }^{\circ} \mathrm{C}$ for $10 \mathrm{~s}$, and polymerization at $72{ }^{\circ} \mathrm{C}$ for $10 \mathrm{~s}$. In order to check the specificity of each amplicon, the melting curve was assessed from $60{ }^{\circ} \mathrm{C}$ to $95^{\circ} \mathrm{C}$ with a slow temperature ramp $\left(0.06^{\circ} \mathrm{C} / \mathrm{s}\right)$ and 10 acquisitions per $1{ }^{\circ} \mathrm{C}$. LightCycler ${ }^{\circledR} 480$ software was used for quantitative analysis. Calibration curves were established for each gene from a serial two-fold dilution of a reference sample (pool of cDNA samples). According to these calibration curves, for each sample, mean relative amounts of mRNA of the targeted genes were calculated and then normalized to that of the reference gene. Using NormFinder software, the gene GAPDH was chosen as a reference gene since it did not exhibit any significant variation of expression among the samples. The normalized means were used for statistical analyses and values were presented as arbitrary units. Three independent experiments were performed.

\subsection{Statistics}

GraphPad Prism software was used for statistical analyses. An analysis of variance (ANOVA) was performed, and, when the effect of concentration was significant $(P<0.05)$, the values were compared to the control using the Dunnett's test. Differences were significant at $P<0.05$. The values presented are means \pm SEM.

\section{Conclusions}

In conclusion, our data provide novel insight on the toxicity of phycotoxins on glial cells present along the gastro-intestinal tract. This study demonstrated that EGCs are sensitive to most of the tested phycotoxins, with the exception of SPX.

Globally, our results suggest that the response of phycotoxins on the intestinal epithelium may involve the enteric nervous system and that EGCs may play a role in the symptoms induced by OA, AZA1, and PITX in humans. Although no effects have been reported in humans from PTX2 and YTX, these toxins could affect EGCs. Further toxicological investigations are required to elucidate the role of EGCs in the acute toxicity of phycotoxins.

Supplementary Materials: The following are available online at http://www.mdpi.com/1660-3397/17/7/429/s1, Table S1: Summary of primers used for qPCR analysis, Table S2: Relative gene expression in EGCs after $24 \mathrm{~h}$ exposure to PTX2, YTX and AZA1.

Author Contributions: Conceived and designed the experiments: O.R., A.H. and V.F. Performed the experiments: O.R. Analyzed the data: O.R., A.H. and V.F. Wrote the paper: O.R., A.H. and V.F.

Funding: This research received no external funding.

Acknowledgments: We thank Hogeveen Kevin for his support in HCA.

Conflicts of Interest: The authors declare no conflict of interest.

\section{References}

1. Farabegoli, F.; Blanco, L.; Rodriguez, L.P.; Vieites, J.M.; Cabado, A.G. Phycotoxins in marine shellfish: Origin, occurrence and effects on humans. Mar. Drugs 2018, 16, 188. [CrossRef] [PubMed]

2. Khora, S.S.; Jal, S. Occurrence of natural toxins in seafood. Microb. Contam. Food Degrad. 2018, 177-233. [CrossRef]

3. EFSA. Marine biotoxins in shellfish-Pectenotoxin group. EFSA J. 2009, 7, 1109.

4. EFSA. Marine biotoxins in shellfish-Yessotoxin group. EFSA J. 2008, 7, 907. 
5. Özogul, F.; Hamed, I. Marine-based toxins and their health risk. In Handbook of Food Bioengineering, Food Quality: Balancing Health and Disease; Holban, A.M., Grumezescu, A.M., Eds.; Academic Press: Cambridge, MA, USA, 2018; Chapter 3; Volume 13, pp. 109-144.

6. EFSA. Marine biotoxins in shellfish-Azaspiracid group. EFSA J. 2008, 6, 723.

7. EFSA. Scientific Opinion on marine biotoxins in shellfish-Cyclic imines (spirolides, gymnodimines, pinnatoxins and pteriatoxins). EFSA J. 2010, 8, 1628. [CrossRef]

8. EFSA. Scientific Opinion on marine biotoxins in shellfish-Palytoxin group. EFSA J. 2009, 7, 1393. [CrossRef]

9. Espina, B.; Rubiolo, J.A. Marine toxins and the cytoskeleton: Pectenotoxins, unusual macrolides that disrupt actin. FEBS J. 2008, 275, 6082-6088. [CrossRef]

10. Twiner, M.J.; Hess, P.; Dechraoui, M.Y.; McMahon, T.; Samons, M.S.; Satake, M.; Yasumoto, T.; Ramsdell, J.S.; Doucette, G.J. Cytotoxic and cytoskeletal effects of azaspiracid-1 on mammalian cell lines. Toxicon 2005, 45, 891-900. [CrossRef]

11. Takai, A.; Sasaki, K.; Nagai, H.; Mieskes, G.; Isobe, M.; Isono, K.; Yasumoto, T. Inhibition of specific binding of okadaic acid to protein phosphatase $2 \mathrm{~A}$ by microcystin-LR, calyculin-A and tautomycin: Method of analysis of interactions of tight-binding ligands with target protein. Biochem. J. 1995, 306, 657-665. [CrossRef]

12. Alexander, J.; Atli Auðunsson, G.A.; Benford, D.; Cockburn, A.; Cravedi, J.P.; Dogliotti, E.; Di Domenico, A.; Fernández-Cruz, M.L.; Fink-Gremmels, J.; Fürst, P.; et al. Marine biotoxins in shellfish-Okadaic acid and analogues, Scientific Opinion of the Panel on Contaminants in the Food chain. EFSA J. 2008, 589, 1-62.

13. Otero, A.; Chapela, M.J.; Atanassova, M.; Vieites, J.M.; Cabado, A.G. Cyclic imines: Chemistry and mechanism of action: A review. Chem. Res. Toxicol. 2011, 24, 1817-1829. [CrossRef] [PubMed]

14. Patocka, J.; Nepovimova, E.; Wu, Q.; Kuca, K. Palytoxin congeners. Arch. Toxicol. 2018, 92, $143-156$. [CrossRef] [PubMed]

15. De la Rosa, L.A.; Alfonso, A.; Vilarino, N.; Vieytes, M.R.; Botana, L.M. Modulation of cytosolic calcium levels of human lymphocytes by yessotoxin, a novel marine phycotoxin. Biochem. Pharmacol. 2001, 61, 827-833. [CrossRef]

16. Paz, B.; Daranas, A.H.; Norte, M.; Riobo, P.; Franco, J.M.; Fernandez, J.J. Yessotoxins, a group of marine polyether toxins: An overview. Mar. Drugs 2008, 6, 73-102. [CrossRef]

17. Twiner, M.J.; Rehmann, N.; Hess, P.; Doucette, G.J. Azaspiracid shellfish poisoning: A review on the chemistry, ecology, and toxicology with an emphasis on human health impacts. Mar. Drugs 2008, 6, 39-72. [CrossRef]

18. Terao, K.; Ito, E.; Yanagi, T.; Yasumoto, T. Histopathological studies on experimental marine toxin poisoning. I. Ultrastructural changes in the small intestine and liver of suckling mice induced by dinophysistoxin- 1 and pectenotoxin-1. Toxicon 1986, 24, 1141-1151. [CrossRef]

19. Aune, T.; Espenes, A.; Aasen, J.A.; Quilliam, M.A.; Hess, P.; Larsen, S. Study of possible combined toxic effects of azaspiracid-1 and okadaic acid in mice via the oral route. Toxicon 2012, 60, 895-906. [CrossRef]

20. Ito, E.; Satake, M.; Ofuji, K.; Higashi, M.; Harigaya, K.; McMahon, T.; Yasumoto, T. Chronic effects in mice caused by oral administration of sublethal doses of azaspiracid, a new marine toxin isolated from mussels. Toxicon 2002, 40, 193-203. [CrossRef]

21. Fernandez, D.A.; Louzao, M.C.; Vilarino, N.; Espina, B.; Fraga, M.; Vieytes, M.R.; Roman, A.; Poli, M.; Botana, L.M. The kinetic, mechanistic and cytomorphological effects of palytoxin in human intestinal cells (Caco-2) explain its lower-than-parenteral oral toxicity. FEBS J. 2013, 280, 3906-3919. [CrossRef]

22. Ferron, P.J.; Hogeveen, K.; Fessard, V.; Le Hegarat, L. Comparative analysis of the cytotoxic effects of okadaic acid-group toxins on human intestinal cell lines. Mar. Drugs 2014, 12, 4616-4634. [CrossRef] [PubMed]

23. Le Hegarat, L.; Jacquin, A.G.; Bazin, E.; Fessard, V. Genotoxicity of the marine toxin okadaic acid, in human Caco-2 cells and in mice gut cells. Environ. Toxicol. 2006, 21, 55-64. [CrossRef] [PubMed]

24. Neunlist, M.; Van Landeghem, L.; Mahe, M.M.; Derkinderen, P.; des Varannes, S.B.; Rolli-Derkinderen, M. The digestive neuronal-glial-epithelial unit: A new actor in gut health and disease. Nat. Rev. Gastroenterol. Hepatol. 2013, 10, 90-100. [CrossRef] [PubMed]

25. Cabarrocas, J.; Savidge, T.C.; Liblau, R.S. Role of enteric glial cells in inflammatory bowel disease. Glia 2003, 41, 81-93. [CrossRef] [PubMed]

26. Neunlist, M.; Van Landeghem, L.; Bourreille, A.; Savidge, T. Neuro-glial crosstalk in inflammatory bowel disease. J. Intern. Med. 2008, 263, 577-583. [CrossRef] [PubMed]

27. Ben-Horin, S.; Chowers, Y. Neuroimmunology of the gut: Physiology, pathology, and pharmacology. Curr. Opin. Pharmcol. 2008, 8, 490-495. [CrossRef] [PubMed] 
28. Yu, J.; Carrier, R.L.; March, J.C.; Griffith, L.G. Three dimensional human small intestine models for ADME-Tox studies. Drug Discov. Today 2014, 19, 1587-1594. [CrossRef] [PubMed]

29. Neunlist, M.; Aubert, P.; Bonnaud, S.; Van Landeghem, L.; Coron, E.; Wedel, T.; Naveilhan, P.; Ruhl, A.; Lardeux, B.; Savidge, T.; et al. Enteric glia inhibit intestinal epithelial cell proliferation partly through a TGF-beta1-dependent pathway. Am. J. Physiol. Gastrointest. Liver Physiol. 2007, 292, G231-G241. [CrossRef]

30. Kermarrec, L.; Durand, T.; Neunlist, M.; Naveilhan, P.; Neveu, I. Enteric glial cells have specific immunosuppressive properties. J. Neuroimmunol. 2016, 295-296, 79-83. [CrossRef]

31. Ochoa-Cortes, F.; Turco, F.; Linan-Rico, A.; Soghomonyan, S.; Whitaker, E.; Wehner, S.; Cuomo, R.; Christofi, F.L. Enteric glial cells: A new frontier in neurogastroenterology and clinical target for inflammatory bowel diseases. Inflamm. Bowel Dis. 2016, 22, 433-449. [CrossRef]

32. Langness, S.; Kojima, M.; Coimbra, R.; Eliceiri, B.P.; Costantini, T.W. Enteric glia cells are critical to limiting the intestinal inflammatory response after injury. Am. J. Physiol. Gastrointest. Liver Physiol. 2017, 312, G274-G282. [CrossRef] [PubMed]

33. Gulbransen, B.D. Enteric Glia. Colloquim Ser. Neurogl. Biol. Med. Physiol. Dis. 2014, 1, 1-72. [CrossRef]

34. Bach-Ngohou, K.; Mahe, M.M.; Aubert, P.; Abdo, H.; Boni, S.; Bourreille, A.; Denis, M.G.; Lardeux, B.; Neunlist, M.; Masson, D. Enteric glia modulate epithelial cell proliferation and differentiation through 15-deoxy-12,14-prostaglandin J2. J. Physiol. 2010, 588 Pt 14, 2533-2544. [CrossRef]

35. Gulbransen, B.D.; Sharkey, K.A. Novel functional roles for enteric glia in the gastrointestinal tract. Nat. Rev. Gastroenterol. Hepatol. 2012, 9, 625-632. [CrossRef] [PubMed]

36. Espina, B.; Otero, P.; Louzao, M.C.; Alfonso, A.; Botana, L.M. 13-Desmethyl spirolide-c and 13,19-didesmethyl spirolide-c trans-epithelial permeabilities: Human intestinal permeability modelling. Toxicology 2011, 287, 69-75. [CrossRef] [PubMed]

37. Ehlers, A.; Scholz, J.; These, A.; Hessel, S.; Preiss-Weigert, A.; Lampen, A. Analysis of the passage of the marine biotoxin okadaic acid through an in vitro human gut barrier. Toxicology 2011, 279, 196-202. [CrossRef] [PubMed]

38. Louzao, M.C.; Fernandez, D.A.; Abal, P.; Fraga, M.; Vilarino, N.; Vieytes, M.R.; Botana, L.M. Diarrhetic effect of okadaic acid could be related with its neuronal action: Changes in neuropeptide Y. Toxicol. Lett. 2015, 237, 151-160. [CrossRef]

39. Boesmans, W.; Cirillo, C.; Van den Abbeel, V.; Van den Haute, C.; Depoortere, I.; Tack, J.; Vanden Berghe, P. Neurotransmitters involved in fast excitatory neurotransmission directly activate enteric glial cells. Neurogastroenterol. Motil. 2013, 25, e151-e160. [CrossRef]

40. Le Berre-Scoul, C.; Chevalier, J.; Oleynikova, E.; Cossais, F.; Talon, S.; Neunlist, M.; Boudin, H. A novel enteric neuron-glia coculture system reveals the role of glia in neuronal development. J. Physiol. 2017, 595, 583-598. [CrossRef]

41. Espina, B.; Louzao, M.C.; Ares, I.R.; Cagide, E.; Vieytes, M.R.; Vega, F.V.; Rubiolo, J.A.; Miles, C.O.; Suzuki, T.; Yasumoto, T.; et al. Cytoskeletal toxicity of pectenotoxins in hepatic cells. Br. J. Pharmol. 2008, 155, 934-944. [CrossRef]

42. Vilarino, N. Marine toxins and the cytoskeleton: Azaspiracids. FEBS J. 2008, 275, 6075-6081. [CrossRef] [PubMed]

43. Diogène, G.; Fessard, V.; Dubreuil, A.; Puisseux-Dao, S. Comparative studies of the actin cytoskeleton response to Maitotoxin and Okadaic Acid. Toxicol. In Vitro 1995, 9, 1-10. [CrossRef]

44. Valverde, I.; Lago, J.; Vieites, J.M.; Cabado, A.G. In vitro approaches to evaluate palytoxin-induced toxicity and cell death in intestinal cells. J. Appl. Toxicol. 2008, 28, 294-302. [CrossRef]

45. Rossini, G.P.; Hess, P. Phycotoxins: Chemistry, mechanisms of action and shellfish poisoning. Mol. Clin. Environ. Toxicol. 2010, 100, 65-122.

46. Vilarino, N.; Nicolaou, K.C.; Frederick, M.O.; Cagide, E.; Alfonso, C.; Alonso, E.; Ares, I.R.; Louzao, M.C.; Vieytes, M.R.; Botana, L.M. Cell Growth Inhibition and Actin Cytoskeleton Disorganization Induced by Azaspiracid-1 Structure-Activity Studies. Chem. Res. Toxicol. 2006, 19, 1456-1466. [CrossRef]

47. Botana, L.M.; Alfonso, A.; Vale, C.; Vilariño, N.; Rubiolo, J.; Alonso, E.; Cagide, E. The mechanistic complexities of phycotoxins: Toxicology of azaspiracids and yessotoxins. Adv. Mol. Toxicol. 2014, 8, 1-33.

48. Roman, Y.; Alfonso, A.; Louzao, M.C.; de la Rosa, L.A.; Leira, F.; Vieites, J.M.; Vieytes, M.R.; Ofuji, K.; Satake, M.; Yasumoto, T.; et al. Azaspiracid-1, a potent, nonapoptotic new phycotoxin with several cell targets. Cell. Signal. 2002, 14, 703-716. [CrossRef] 
49. Munday, R.; Quilliam, M.A.; LeBlanc, P.; Lewis, N.; Gallant, P.; Sperker, S.A.; Ewart, H.S.; MacKinnon, S.L. Investigations into the toxicology of spirolides, a group of marine phycotoxins. Toxins 2012, 4, 1-14. [CrossRef]

50. Ares, I.R.; Louzao, M.C.; Espina, B.; Vieytes, M.R.; Miles, C.O.; Yasumoto, T.; Botana, L.M. Lactone ring of pectenotoxins: A key factor for their activity on cytoskeletal dynamics. Cell. Physiol. Biochem. 2007, 19, 283-292. [CrossRef]

51. Von Boyen, G.B.T. Proinflammatory cytokines increase glial fibrillary acidic protein expression in enteric glia. Gut 2004, 53, 222-228. [CrossRef]

52. Rolland, B.; Le Prince, G.; Fages, C.; Nunez, J.; Tardy, M. GFAP turnover during astroglial proliferation and differentiation. Brain Res. Dev. Brain Res. 1990, 56, 144-149. [CrossRef]

53. Moody, L.; Barrett-Wilt, G.; Sussman, M.; Messing, A. Glial fibrillary acidic protein exhibits altered turnover kinetics in a mouse model of Alexander disease. J. Biol. Chem. 2017, 292, 5814-5824. [CrossRef] [PubMed]

54. Brahmachari, S.; Fung, Y.K.; Pahan, K. Induction of glial fibrillary acidic protein expression in astrocytes by nitric oxide. J. Neurosci. 2006, 18, 4930-4939. [CrossRef] [PubMed]

55. Rosenbaum, C.; Schick, M.A.; Wollborn, J.; Heider, A.; Scholz, C.J.; Cecil, A.; Niesler, B.; Hirrlinger, J.; Walles, H.; Metzger, M. Activation of myenteric glia during acute inflammation in vitro and in vivo. PLoS ONE 2016, 11, e0151335. [CrossRef] [PubMed]

56. Franchini, A.; Malagoli, D.; Ottaviani, E. Targets and Effects of Yessotoxin, Okadaic Acid and Palytoxin: A Differential Review. Mar. Drugs 2010, 8, 658-677. [CrossRef] [PubMed]

57. Sonoda, Y.; Kasahara, T.; Yamaguchi, Y.; Kuno, K.; Matsushima, K.; Mukaida, N. Stimulation of interleukin-8 production by okadaic acid and vanadate in a human promyelocyte cell line, an HL-60 subline. Possible role of mitogen-activated protein kinase on the okadaic acid-induced NF-kappaB activation. J. Biol. Chem. 1997, 272, 15366-15372. [CrossRef] [PubMed]

58. Rieckmann, P.; Thévenin, C.; Kehrl, J.H. Okadaic acid is a potent inducer of AP-1, NF-kappa B, and tumor necrosis factor-alpha in human B lymphocytes. Biochem. Biophys. Res. Commun. 1992, 187, 51-57. [CrossRef]

59. Gupta, S.C.; Sundaram, C.; Reuter, S.; Aggarwal, B.B. Inhibiting NF-kappaB activation by small molecules as a therapeutic strategy. Biochim. Biophys. Acta 2010, 1799, 775-787. [CrossRef]

60. Nezami, B.G.; Srinivasan, S. Enteric nervous system in the small intestine: Pathophysiology and clinical implications. Curr. Gastroenterol. Rep. 2010, 12, 358-365. [CrossRef] [PubMed]

61. Kim, M.O.; Moon, D.O.; Heo, M.S.; Lee, J.D.; Jung, J.H.; Kim, S.K.; Choi, Y.H.; Kim, G.Y. Pectenotoxin-2 abolishes constitutively activated NF- $\mathrm{kB}$, leading to suppression of NF- $\mathrm{B}$ related gene products and potentiation of apoptosis. Cancer Lett. 2008, 271, 25-33. [CrossRef]

62. Esposito, G.; Capoccia, E.; Turco, F.; Palumbo, I.; Lu, J.; Steardo, A.; Cuomo, R.; Sarnelli, G.; Steardo, L. Palmitoylethanolamide improves colon inflammation through an enteric glia/toll like receptor 4-dependent PPAR-alpha activation. Gut 2014, 63, 1300-1312. [CrossRef] [PubMed]

63. Cirillo, C.; Sarnelli, G.; Turco, F.; Mango, A.; Grosso, M.; Aprea, G.; Masone, S.; Cuomo, R. Proinflammatory stimuli activates human-derived enteroglial cells and induces autocrine nitric oxide production. Neurogastroenterol. Motil. 2011, 23, e372-e382. [CrossRef] [PubMed]

64. Grubisic, V.; Gulbransen, B.D. Enteric glia: The most alimentary of all glia. J. Physiol. 2017, 595, 557-570. [CrossRef] [PubMed]

65. Cirillo, C.; Sarnelli, G.; Esposito, G.; Turco, F.; Steardo, L.; Cuomo, R. S100B protein in the gut: The evidence for enteroglial-sustained intestinal inflammation. World J. Gastroenterol. 2011, 17, 1261-1266. [CrossRef] [PubMed]

66. Donato, R. Functional roles of $\mathrm{S} 100$ proteins, calcium-binding proteins of the EF-hand type. Biochim. Et Biophys. Acta 1999, 1450, 191-231. [CrossRef]

67. Frizzo, K.J.; Tramontina, F.; Bortoli, E.; Gottfried, C.; Leal, R.B.; Lengyel, I.; Donato, R.; Dunkley, P.R.; Gonçalves, C.A. S100B-mediated inhibition of phosphorylation of GFAP is prevented by TRTK-12. Neurochem. Res. 2004, 29, 735-740. [CrossRef] [PubMed]

68. Donato, R.; Sorci, G.; Riuzzi, F.; Arcuri, C.; Bianchi, R.; Brozzi, F.; Tubaro, C.; Giambanco, I. S100B's double life: Intracellular regulator and extracellular signal. Biochim. Biophys. Acta 2009, 1793, 1008-1022. [CrossRef] [PubMed]

69. Chow, A.K.; Gulbransen, B.D. Potential roles of enteric glia in bridging neuroimmune communication in the gut. Am. J. Physiol. Gastrointest. Liver Physiol. 2017, 312, G145-G152. [CrossRef] 
70. Xiao, W.; Wang, W.; Chen, W.; Sun, L.; Li, X.; Zhang, C.; Yang, H. GDNF is involved in the barrier-inducing effect of enteric glial cells on intestinal epithelial cells under acute ischemia reperfusion stimulation. Mol. Neurobiol. 2014, 50, 274-289. [CrossRef]

71. Xiao, W.D.; Chen, W.; Sun, L.H.; Wang, W.S.; Zhou, S.W.; Yang, H. The protective effect of enteric glial cells on intestinal epithelial barrier function is enhanced by inhibiting inducible nitric oxide synthase activity under lipopolysaccharide stimulation. Mol. Cell. Neurosci. 2011, 46, 527-534. [CrossRef]

72. Razafimanjato, H.; Garmy, N.; Guo, X.J.; Varini, K.; Di Scala, C.; Di Pasquale, E.; Taieb, N.; Maresca, M. The food-associated fungal neurotoxin ochratoxin A inhibits the absorption of glutamate by astrocytes through a decrease in cell surface expression of the excitatory amino-acid transporters GLAST and GLT-1. Neurotoxicology 2010, 31, 475-484. [CrossRef] [PubMed]

73. Tian, J.; Kim, S.F.; Hester, L.; Snyder, S.H. S-nitrosylation/activation of COX-2 mediates NMDA neurotoxicity. PNAS 2008, 105, 10537-10540. [CrossRef] [PubMed]

74. Khan, M.; Sekhon, B.; Giri, S.; Jatana, M.; Gilg, A.G.; Ayasolla, K.; Elango, C.; Singh, A.K.; Singh, I. S-Nitrosoglutathione reduces inflammation and protects brain against focal cerebral ischemia in a rat model of experimental stroke. J. Cereb. Blood Flow Metab. 2005, 25, 177-192. [CrossRef] [PubMed]

75. Franchini, A.; Marchesini, E.; Poletti, R.; Ottaviani, E. Acute toxic effect of the algal yessotoxin on Purkinje cells from the cerebellum of Swiss CD1 mice. Toxicon 2004, 43, 347-352. [CrossRef] [PubMed]

76. Shin, D.Y.; Kim, G.Y.; Kim, N.D.; Jung, J.H.; Kim, S.K.; Kang, H.S.; Choi, Y.H. Induction of apoptosis by pectenotoxin-2 is mediated with the induction of DR4/DR5, Egr-1 and NAG-1, activation of caspases and modulation of the Bcl-2 family in 53-deficient Hep3B hepatocellular carcinoma cells. Oncol. Rep. 2008, 19, 517-526. [CrossRef]

77. Leira, F.; Alvarez, C.; Vieites, J.M.; Vieytes, M.R.; Botana, L.M. Characterization of distinct apoptotic changes induced by okadaic acid and yessotoxin in the BE(2)-M17 neuroblastoma cell line. Toxicol. In Vitro 2002, 16, 23-31. [CrossRef]

78. Malaguti, C.; Ciminiello, P.; Fattorusso, E.; Rossini, G.P. Caspase activation and death induced by yessotoxin in HeLa cells. Toxicol. In Vitro 2002, 16, 357-363. [CrossRef]

79. Rossini, G.P.; Sgarbi, N.; Malaguti, C. The toxic responses induced by okadaic acid involve processing of multiple caspase isoformsinvolve caspase. Toxicon 2001, 39, 763-770. [CrossRef]

80. Kitazumi, I.; Maseki, Y.; Nomura, Y.; Shimanuki, A.; Sugita, Y.; Tsukahara, M. Okadaic acid induces DNA fragmentation via caspase-3-dependent and caspase-3-independent pathways in Chinese hamster ovary (CHO)-K1 cells. FEBS J. 2010, 277, 404-412. [CrossRef]

81. Cao, Z.; LePage, K.T.; Frederick, M.O.; Nicolaou, K.C.; Murray, T.F. Involvement of caspase activation in azaspiracid-induced neurotoxicity in neocortical neurons. Toxicol. Sci. 2010, 114, 323-334. [CrossRef]

82. Vilarino, N.; Nicolaou, K.C.; Frederick, M.O.; Vieytes, M.R.; Botana, L.M. Irreversible cytoskeletal disarrangement is independent of caspase activation during in vitro azaspiracid toxicity in human neuroblastoma cells. Biochem. Pharmol. 2007, 74, 327-335. [CrossRef] [PubMed]

83. Shin, I.K.; Ahn, Y.T.; Kim, Y.; Kim, J.M.; An, W.G. Actin disruption agents induce phosphorylation of histone H2AX in human breast adenocarcinoma MCF-7 cells. Oncol. Rep. 2011, 25, 1313-1319. [PubMed]

84. Valdiglesias, V.; Méndez, J.; Pásaro, E.; Cemelic, E.; Anderson, D.; Laffon, B. Assessment of okadaic acid effects on cytotoxicity, DNA damage and DNA repair in human cells. Mutat. Res. Fundam. Mol. Mech. Mutagenesis 2010, 689, 74-79. [CrossRef] [PubMed]

85. Korsnes, M.S.; Korsnes, R. Mitotic catastrophe in BC3H1 CELLS following yessotoxin exposure. Front. Cell Dev. Biol. 2017, 5, 30. [CrossRef] [PubMed]

86. Moon, D.-O.; Kim, M.-O.; Kang, S.-H.; Lee, K.-J.; Heo, M.-S.; Choi, K.-S.; Choi, Y.H.; Kim, G.-Y. Induction of G2/M arrest, endoreduplication, and apoptosis by actin depolymerization agent pextenotoxin-2 in human leukemia cells, involving activation of ERK and JNK. Biochem. Pharmacol. 2008, 76, 312-321. [CrossRef] [PubMed]

87. Moon, D.O.; Kim, M.O.; Nam, T.J.; Kim, S.K.; Choi, Y.H.; Kim, G.Y. Pectenotoxin-2 induces G2/M phase cell cycle arrest in human breast cancer cells via ATM and Chk1/2-mediated phosphorylation of cdc25C. Oncol. Rep. 2010, 24, 271-276. [PubMed]

88. Hori, M.; Yazama, F.; Matsuura, Y.; Yoshimoto, R.; Kaneda, T.; Yasumoto, T.; Ozaki, H.; Karaki, H. Inhibition of actin polymerization by marine toxin pectenotoxin-2. J. Vet. Med. Sci. 2018, 80, 225-234. [CrossRef] [PubMed] 
89. Kim, G.Y.; Kim, W.J.; Choi, Y.H. Pectenotoxin-2 from marine sponges: A potential anti-cancer agent-A review. Mar. Drugs 2011, 9, 2176-2187. [CrossRef] [PubMed]

90. Martin-Lopez, A.; Gallardo-Rodriguez, J.J.; Sanchez-Miron, A.; Garcia-Camacho, F.; Molina-Grima, E. Cytotoxicity of yessotoxin and okadaic acid in mouse T lymphocyte cell line EL-4. Toxicon 2012, 60, 1049-1056. [CrossRef] [PubMed]

91. Edelstein, J.; Rockwell, P. Okadaic acid induces Akt hyperphosphorylation and an oxidative stress-mediated cell death in serum starved SK-N-SH human neuroblastoma cells that are augmented by rapamycin. Neurosci. Lett. 2012, 531, 74-79. [CrossRef]

92. Schmidt, K.N.; Traenckner, E.B.M.; Meier, B.; Baeuerle, P.A. Induction of oxidative stress by okadaic acid is required for activation of transcription factor NF-кB. J. Biol. Chem. 1995, 270, 27136-27142. [CrossRef] [PubMed]

93. Ravindran, J.; Gupta, N.; Agrawal, M.; Bala Bhaskar, A.S.; Lakshmana Rao, P.V. Modulation of ROS/MAPK signaling pathways by okadaic acid leads to cell death via, mitochondrial mediated caspase-dependent mechanism. Apoptosis 2011, 16, 145-161. [CrossRef] [PubMed]

94. Vale, C.; Nicolaou, K.C.; Frederick, M.O.; Vieytes, M.R.; Botana, L.M. Cell volume decrease as a link between azaspiracid-induced cytotoxicity and c-Jun-N-terminal kinase activation in cultured neurons. Toxicol. Sci. 2010, 113, 158-168. [CrossRef] [PubMed]

95. Hjornevik, L.V.; Froyset, A.K.; Gronset, T.A.; Rungruangsak-Torrissen, K.; Fladmark, K.E. Algal toxin azaspiracid-1 induces early neuronal differentiation and alters peripherin isoform stoichiometry. Mar. Drugs 2015, 13, 7390-7402. [CrossRef] [PubMed]

96. Meir, M.; Flemming, S.; Burkard, N.; Bergauer, L.; Metzger, M.; Germer, C.T.; Schlegel, N. Glial cell line-derived neurotrophic factor promotes barrier maturation and wound healing in intestinal epithelial cells in vitro. Am. J. Physiol. Gastrointest. Liver Physiol. 2015, 309, G613-G624. [CrossRef]

97. Von Boyen, G.B.; Steinkamp, M.; Geerling, I.; Reinshagen, M.; Schafer, K.H.; Adler, G.; Kirsch, J. Proinflammatory cytokines induce neurotrophic factor expression in enteric glia: A key to the regulation of epithelial apoptosis in Crohn's disease. Inflamm. Bowel Dis. 2006, 12, 346-354. [CrossRef]

98. Steinkamp, M.; Gundel, H.; Schulte, N.; Spaniol, U.; Pflueger, C.; Zizer, E.; von Boyen, G.B. GDNF protects enteric glia from apoptosis: Evidence for an autocrine loop. BMC Gastroenterol. 2012, 12, 6. [CrossRef]

99. Steinkamp, M.; Schulte, N.; Spaniol, U.; Pflueger, C.; Hartmann, C.; Kirsch, J.; von Boyen, G.B. Brain derived neurotrophic factor inhibits apoptosis in enteric glia during gut inflammation. Med. Sci. Monit. 2012, 18, 117-122.

100. Neunlist, M.; Rolli-Derkinderen, M.; Latorre, R.; Van Landeghem, L.; Coron, E.; Derkinderen, P.; De Giorgio, R. Enteric glial cells: Recent developments and future directions. Gastroenterology 2014, 147, 1230-1237. [CrossRef]

101. Yoo, B.B.; Mazmanian, S.K. The Enteric Network: Interactions between the Immune and Nervous Systems of the Gut. Immunity 2017, 46, 910-926. [CrossRef]

102. Pelin, M.; Sosa, S.; Pacor, S.; Tubaro, A.; Florio, C. The marine toxin palytoxin induces necrotic death in HaCaT cells through a rapid mitochondrial damage. Toxicol. Lett. 2014, 229, 440-450. [CrossRef] [PubMed]

103. Pelin, M.; Ponti, C.; Sosa, S.; Gibellini, D.; Florio, C.; Tubaro, A. Oxidative stress induced by palytoxin in human keratinocytes is mediated by a H+-dependent mitochondrial pathway. Toxicol. Appl. Pharmol. 2013, 266, 1-8. [CrossRef] [PubMed]

104. Wang, D.Z. Neurotoxins from marine dinoflagellates: A brief review. Mar. Drugs 2008, 6, 349-371. [CrossRef] [PubMed]

105. Delvalle, N.M.; Fried, D.E.; Rivera-Lopez, G.; Gaudette, L.; Gulbransen, B.D. Cholinergic activation of enteric glia is a physiological mechanism that contributes to the regulation of gastrointestinal motility. Gastrointest. Liver Physiol. 2018, 315, 473-483. [CrossRef] [PubMed]

106. Wandscheer, C.B.; Vilarino, N.; Espina, B.; Louzao, M.C.; Botana, L.M. Human muscarinic acetylcholine receptors are a target of the marine toxin 13-desmethyl C spirolide. Chem. Res. Toxicol. 2010, 23, 1753-1761. [CrossRef]

107. Araoz, R.; Ouanounou, G.; Iorga, B.I.; Goudet, A.; Alili, D.; Amar, M.; Benoit, E.; Molgo, J.; Servent, D. The neurotoxic effect of 13,19-didesmethyl and 13-desmethyl spirolide C phycotoxins is mainly mediated by nicotinic rather than muscarinic acetylcholine receptors. Toxicol. Sci. 2015, 147, 156-167. [CrossRef] [PubMed] 
108. Alexander, J.; Benford, D.; Boobis, A.; Ceccatelli, S.; Cravedi, J.P.; Di Domenico, A.; Doerge, D.; Dogliotti, E.; Edler, L.; Farmer, P.; et al. Marine biotoxins in shellfish-Summary on regulated marine biotoxins, Scientific opinion of the panel on contaminants in the food chain. EFSA J. 2009, 1306, 1-23.

109. Ferron, P.J.; Hogeveen, K.; De Sousa, G.; Rahmani, R.; Dubreil, E.; Fessard, V.; Le Hegarat, L. Modulation of CYP3A4 activity alters the cytotoxicity of lipophilic phycotoxins in human hepatic HepaRG cells. Toxicol. In Vitro 2016, 33, 136-146. [CrossRef]

110. Huguet, A.; Hatton, A.; Villot, R.; Quenault, H.; Blanchard, Y.; Fessard, V. Modulation of chromatin remodelling induced by the freshwater cyanotoxin cylindrospermopsin in human intestinal Caco-2 cells. PLOS ONE 2014, 9, e99121. [CrossRef]

(C) 2019 by the authors. Licensee MDPI, Basel, Switzerland. This article is an open access article distributed under the terms and conditions of the Creative Commons Attribution (CC BY) license (http://creativecommons.org/licenses/by/4.0/). 